\title{
Complex Organic Fouling and Effect of Silver Nanoparticles on Aquaporin Forward Osmosis Membranes
}

Arman Balkenov ${ }^{\dagger, 1,2}$, Amire Anuarbek ${ }^{\dagger, 1,2}$, Aliya Satayeva ${ }^{1,2}$, Jong Kim ${ }^{1}$, Vassilis Inglezakis ${ }^{2,3,4}$, Elizabeth Arkhangelsky ${ }^{1,2,4 *}$

$\dagger$ These authors contributed equally to this work

${ }^{1}$ Department of Civil and Environmental Engineering, School of Engineering, Nazarbayev University, 53 Kabanbay Batyr Avenue, Nur-Sultan 010000, Republic of Kazakhstan
${ }^{2}$ Environmental Science \& Technology Group (ESTg), Nazarbayev University, 53 Kabanbay Batyr Avenue, Nur-Sultan 010000, Republic of Kazakhstan

${ }^{3}$ Department of Chemical and Materials Engineering, School of Engineering, Nazarbayev University, 53 Kabanbay Batyr Avenue, Nur-Sultan 010000, Republic of Kazakhstan

${ }^{4}$ The Environment and Resource Efficiency Cluster (EREC), Nazarbayev University, 53 Kabanbay Batyr Avenue, Nur-Sultan 010000, Republic of Kazakhstan
Department of Civil and Environmental Engineering, School of Engineering, Nazarbayev University, 53 Kabanbay Batyr Avenue, Nur-Sultan 010000, Republic of Kazakhstan Tel.: + 77172709118 Email address: yelyzaveta.arkhangelsky@nu.edu.kz (E. Arkhangelsky) 


\section{Abstract}

29

Despite the negligible pressure used in forward osmosis (FO), the process still suffers from fouling. Recent studies demonstrated that this issue is common among all FO membrane types, including aquaporin-based filters. To address this problem, various approaches have been proposed. However, despite the biocidal effects of silver, no attempt has been made to apply silver for fouling mitigation in aquaporin FO membranes. Consequently, the present work focuses on the investigation of controlled combined organic fouling of aquaporin FO membranes and the effects of silver nanoparticles on the membrane performance and its properties. The obtained data show that in contrast with unaltered membranes, the membranes doped with silver nanoparticles are much more resistant to fouling. After the first filtration run, pristine membranes exhibited a flux decline of $50 \%$, while the flux decline of the modified membranes was limited to 10\%. Physical cleaning restored the flux of both membranes to $100 \%$. Analysis of the membranes showed that the membrane water flux was not affected by the covalent binding of the silver nanoparticles. Further, the membranes' chemistry, zeta potential, contact angle, roughness, and antimicrobial resistance were altered.

Keywords forward osmosis (FO); aquaporin; fouling; cleaning; silver 


\section{Introduction}

The forward osmosis (FO) technique originated in 1963 when Loeb and Sourirajan synthesized the first membrane for the process. Initially, researchers were conducting FO experiments with bladders of various animals (fish, cattle, or pig), nitrocellulose, rubber, or porcelain. However, the process performance was not ideal. In 2010, the widespread adoption FO begun. The number of publications related to FO increased almost 2.5 times [1]. In the FO process a semipermiable membrane - which ideally allows passage of water molecules only - is placed between a feed and a draw solution. The feed is a solution to be treated and its osmotic pressure is low in comparison to the draw. The draw solution possesses high osmotic pressure and pure water is extracted into it. Osmotic gradient arises from the difference in osmotic pressures of the feed and the draw solution [2]. FO was found to be highly energy-efficient and exhibited low fouling propensity, and hence, rarely required cleaning. Moreover, FO produces high-quality product and the applied filters exhibit extended lifetimes compared to that of the filters used in pressuredriven processes. Despite these advantages, FO suffers from several limitations, such as relatively low water flux, back salt diffusion, the necessity to recover the draw solution, the internal concentration polarization phenomenon, and fouling.

Many researchers addressed the disadvantages of the FO technology. For instance, aquaporins -a special class of proteins-were used to improve water permeability. Indeed, a substantial number of studies demonstrated that the incorporation of aquaporins from E. Coli to the selective layer of FO membranes increases water flux $[3,4]$. On the contrary, limited number of publications were dedicated to the investigation of fouling of aquaporin FO membranes. For example, Singh et al. [5] investigated the dewatering of sewage and found that the water flux is affected by the drawsolution concentration and cross-flow velocity of the feed solution. The zeta potential of the membrane became more negative after being exposed to sewage. The authors also found that fouling changes the membrane chemistry, i.e. a new peak $\left(2328 \mathrm{~cm}^{-1}\right.$, which belongs to the $-\mathrm{C}-\mathrm{H}$ 
group) was observed by FTIR analysis. Physical and chemical cleaning performed by water surface rinsing and $0.5 \mathrm{~N}$ sodium hydroxide, respectively, were able to restore the water flux to up to $35-45 \%$. Camilleri-Rumbau et al. [6] applied biogas digestate liquid fractions to aquaporin FO membranes and observed that a $3.5 \mathrm{M}$ sodium chloride draw solution was detrimental to the water flux due to elevated foulant convection towards the membrane. Rinsing the membranes with water (after every 4 hours of fouling) showed an $80-96 \%$ water flux recovery. The cleaning of membranes almost completely recovered the characteristics of the membranes after fouling, reaching levels close to those of pristine membranes. Schneider et al. [7] investigated the treatment of anaerobic digestion effluents by biomimetic FO membranes. They reported that the initial water flux was $4.3-5.1 \mathrm{l} /\left(\mathrm{m}^{2 *} \mathrm{~h}\right)(\mathrm{LMH})$. A maximum of $80 \%$ water flux decline was observed. The chemistry of the membranes was altered by depositing organic and biological foulants. Xu et al. [8] presented the removal of disinfection by-products by aquaporin-based membranes. The membranes demonstrated up to $76 \%$ rejection of disinfection by-products. The introduction of bovine serum albumin (BSA) and alginate into the feed reduced the retention capability of the membranes. Hey et al. [9] studied the treatment of municipal wastewater by aquaporin membranes. The filters exhibited up to $25 \%$ water flux decline after 5 hours of FO. The authors claimed that the pretreatment of the membranes with microsieving and microfiltration was able to reduce the degree of fouling. Ye et al., [10] reported that concentration of $1.9 \mathrm{M}$ sodium carbonate by the biomimetic membrane resulted in > $6 \mathrm{LMH}$ mean water flux in the active layer facing feed solution (AL-FS) orientation. Korenak et al. [11] focused on the treatment of textile wastewater. The authors stated that a fouling layer formed within $21 \mathrm{~h}$ of filtration could be easily removed by the combination of physical (water) and chemical (sodium hydroxide and citric acid) treatments. An additional ten publications that focused on the fouling of aquaporin FO membranes are summarized in Table 1. Aquaporins are a family of proteins that are part of membrane of living cells. They respond to alterations in fluid and are required for fast and regulated fluid secretion and reabsorption [12]. 
Table 1. Summary of studies focusing on fouling in aquaporin FO membranes.

\begin{tabular}{|c|c|c|c|c|c|c|c|}
\hline Feed & Configuration & Pretreatment & Cleaning & $\begin{array}{c}\text { Initial } \\
\text { flux, } \\
\text { LMH }\end{array}$ & $\begin{array}{c}\text { Flux } \\
\text { decline, \% }\end{array}$ & $\begin{array}{c}\text { Flux } \\
\text { restoration, } \\
\%\end{array}$ & Reference \\
\hline $\begin{array}{c}\text { Municipal } \\
\text { Wastewater }\end{array}$ & $\mathrm{FO}$ & $\begin{array}{l}\text { Coagulation, } \\
\text { flocculation, } \\
\text { microwaving, } \\
\text { MF }\end{array}$ & No & $10-15$ & $2-36$ & --- & [13] \\
\hline $\begin{array}{l}\text { Secondary } \\
\text { wastewater } \\
\text { effluent }\end{array}$ & FO & No & $\begin{array}{c}\mathrm{HCl}, \\
\mathrm{NaOCl}, \\
\text { EDTA, } \\
\text { SDS, } \\
\text { Alconox }\end{array}$ & 5 & 0 & $100-200$ & [14] \\
\hline $\begin{array}{c}\text { Dairy } \\
\text { wastewater }\end{array}$ & $\mathrm{FO} / \mathrm{MD}$ & No & No & $6-23$ & $0-65$ & --- & {$[15]$} \\
\hline $\begin{array}{c}\text { Fumaric acid } \\
\text { solution }\end{array}$ & $\mathrm{FO}$ & No & No & $8-17$ & 75 & --- & [16] \\
\hline Humic acid & FO & $\begin{array}{l}\text { Binding } \mathrm{TiO}_{2} \\
\text { nanoparticles }\end{array}$ & No & $6-17$ & $42-82$ & --- & [17] \\
\hline $\begin{array}{c}\text { Synthetic } \\
\text { wastewater }\end{array}$ & MBR & No & No & 12.5 & 28 & --- & [18] \\
\hline $\begin{array}{c}\text { Molasses } \\
\text { distillery } \\
\text { wastewater } \\
\end{array}$ & FO & No & No & $2-7$ & 75 & --- & [19] \\
\hline $\begin{array}{c}\text { Anaerobically } \\
\text { digested } \\
\text { sludge } \\
\text { centrate }\end{array}$ & FO & No & No & $4.5-6$ & $42-62$ & --- & [20] \\
\hline $\begin{array}{l}\text { Crude } \\
\text { glycerol }\end{array}$ & $\mathrm{FO}$ & Fermentation & No & 7.5 & 93 & --- & [21] \\
\hline $\begin{array}{l}\text { Chlorella } \\
\text { vulgaris }\end{array}$ & FO & No & Physical & $2.5-8$ & $0-40$ & 75 & [22] \\
\hline
\end{tabular}

108

109 Only a few papers have thus far reported on fouling-alleviation approaches. Both physical and

110 chemical cleaning were suggested. Additional approaches included increasing the cross-flow

111 velocity at the feed side, reducing the initial water flux, introducing a pretreatment before the FO

112 process, and the attachment of titanium oxide nanoparticles to the membrane. Conversely, the

113 widely known biocidal effects of silver [23-25] have not been applied to aquaporin FO

114 membranes yet. On the contrary, researchers studied the influence of silver on aquaporin 
channels and detected that noble metals-including silver-inhibit the transport of water through aquaporin channels [26-29].

The current work addressed the fouling of aquaporin FO membranes by applying feed solutions of known compositions. Contribution of mono-, di-, and tri-component feed solutions to the water flux decline; the effect of mono- and divalent ions; ionic strength; and spacer type were examined. Subsequently, the membranes were modified by the covalent binding of silver nanoparticles, and the membrane performance was studied. Water flux and flux recovery, ATRFTIR, contact angle, zeta potential, XRD, microscopy, and antimicrobial analysis were used to understand how the binding of silver nanoparticles affects the performance and properties of the membranes. The work focused on investigation of an antifouling strategy by coating the aquaporin based membranes with silver nanoparticles. In comparison to the unaltered membrane, the modified membrane was able to restore water flux during the relaxation period.

\section{Materials and Methods}

\subsection{Membranes}

The FO membrane used in the study was flat-sheet thin film composite (TFC) membrane, aquaporins vesicles/proteoliposomes were embedded into the rejection layer via interfacial polymerization (Aquaporin A/S, DK) [30]. Upon delivery of the membranes to our lab they immediately were employed in FO experiments. The active and support layers of the membranes were made of polyamide and polyethersulfone, respectively. The chemicals used in were purchased from Sigma-Aldrich, USA. All solutions were prepared using Milli-Q water.

\subsection{FO experiments}

The experimental lab-scale setup utilized consisted of a stirrer plate, electronic balance (OHAUS, USA), membrane holder (Sterlitech, USA), and two peristaltic pumps (Cole -Parmer 
141 USA). The draw and feed solutions were placed on the balance and stirrer plates, respectively

142 (Figure 1).

143

144

145

146

147

148

149

150

151

152

153

154

155

156

157

158

159

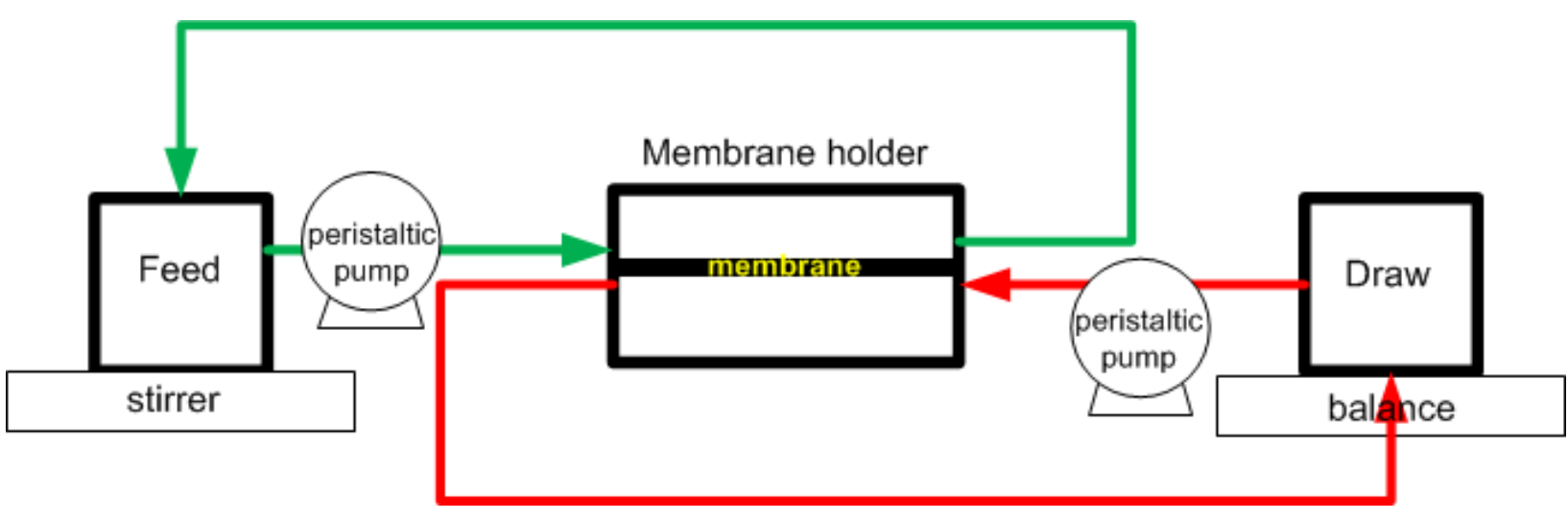

Figure 1. Schematic diagram of lab-scale FO system.

The filtration area of the membrane cell had the dimensions of $4 \mathrm{~cm} \times 8.5 \mathrm{~cm} \times 0.23 \mathrm{~cm}$. The same cross-flow velocities were applied to the draw and feed solutions during every FO experiment. Spacers were used on both sides of the membranes to support the filters. Every experiment was performed on a new membrane and at ambient temperature.

The duration of the fouling experiments was 360 min. 4 M sodium chloride was used as the draw solution. A baseline experiment was performed with a $10 \mathrm{mM} \mathrm{NaCl}$ (Sigma-Aldrich, USA) feed solution. Feed solutions were prepared with 100 ppm sodium alginate (ALG) (Sigma-Aldrich, USA); 100 ppm BSA (Sigma-Aldrich, USA); 100 ppm tannic acid (TA) (Sigma-Aldrich, USA); 10 and $100 \mathrm{mM}$ sodium chloride; 10, 30, and $100 \mathrm{mM}$ calcium chloride (Acros Organics, USA). BSA (protein), alginate (polysaccharide) and tannic acid (organic substance) were used to model Extracellular Polymeric Substance (EPS), which is comprised of polysaccharides, proteins, and other organic substances. The influence of spacers on the process performance was studied by using 47 parallel, 47 diamond, and 17 diamond spacers. The spacers exhibited decreasing porosity: 47 parallel > 47 diamond > 17 diamond (Figure 2). 


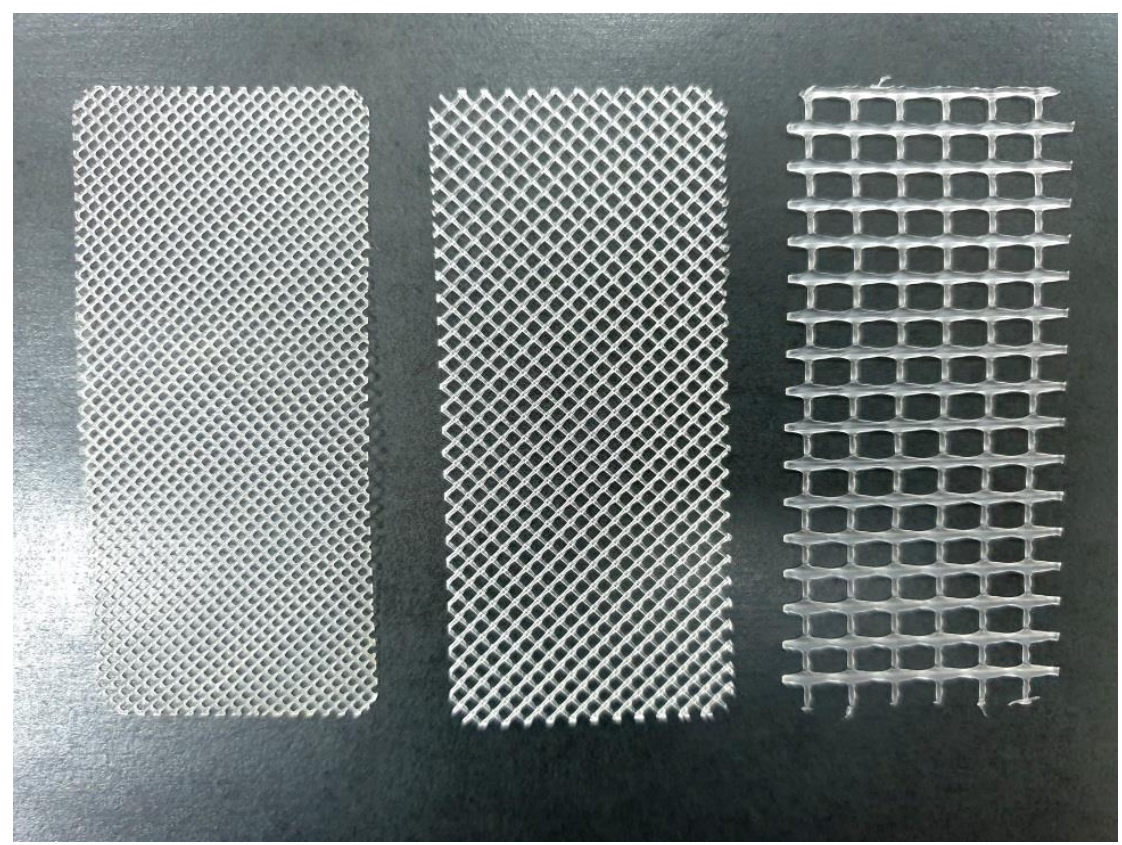

Figure 2. Spacers used in the study; from left to right: 17 diamond, 47 diamond, 47 parallel.

The following operating conditions were employed: FO mode; $12.5 \mathrm{~cm} / \mathrm{s}$ cross-flow velocity; 18

LMH initial water flux; counter-current direction of the feed and draw solutions; and the 47 diamond spacer. To determine the water flux through the membrane, an electronic scale was used.

At this stage, the membrane retention capability is beyond the scope of this work, since the work was aimed to study complex fouling and effect of silver nanoparticles on the water flux of the aquaporin FO membranes. On the use of silver nanoparticles it is planned to extend the work to microbial induced fouling.

\subsection{Synthesis of silver nanoparticles and membrane's modification}

The silver nanoparticles were synthesized based on a modified protocol from Slot and Geuze [31]. $1 \mathrm{ml}$ of $\mathrm{AgNO}_{3}$ (Sigma-Aldrich, USA) (1\%) was added to $79 \mathrm{ml}$ of water (solution I). $4 \mathrm{ml}$ of sodium citrate (Sigma-Aldrich, USA) 1\% was mixed with $0.1 \mathrm{ml}$ of tannic acid $1 \%, 0.1 \mathrm{ml}$ of $\mathrm{K}_{2} \mathrm{CO}_{3}$ (Sigma-Aldrich, USA) $(25 \mathrm{mM})$, and $15.8 \mathrm{ml}$ of distilled water (solution II). The prepared solutions I and II were heated to $60{ }^{\circ} \mathrm{C}$. Solution I was moved to a stirrer plate and 
heated to $100{ }^{\circ} \mathrm{C}$ while being vigorously mixed. When solution I started to boil, solution II was added. After the new solution changed its colour, it was boiled for an additional 3 min and then it was removed from the heating plate. When the solution reached room temperature, its volume was adjusted to $100 \mathrm{ml}$ by adding water.

For the chemical binding of the silver nanoparticles to the polyamide active layer of the membrane, the sample was immersed in a $20 \mathrm{mM}$ cysteamine (Sigma-Aldrich, USA) ethanol solution for $30 \mathrm{~min}$. Subsequently, the membrane was washed with water and incubated in contact with the prepared silver nanoparticle suspension for $12 \mathrm{~h}$. Subsequently, the membrane sample was washed with water and kept at $4{ }^{\circ} \mathrm{C}$ before use [32].

\subsection{Performance of the pristine vs the modified membrane: fouling/cleaning behaviour}

The effect of silver nanoparticles was studied in the $\mathrm{FO}$ mode at a $1.5 \mathrm{~cm} / \mathrm{s}$ cross-flow velocity (reduced cross-flow velocity simulated long-term FO experiments, i.e. real conditions like seawater desalination at desalination plants), $7 \mathrm{LMH}$ initial water flux, counter-current direction of the feed and draw solutions and using a 47 diamond spacer. The duration of the first and the second filtration run was 18 and 6 hours, respectively. In the first run, fouling was implemented in the filtration/relaxation mode, i.e. 6 hour of filtration $\rightarrow 15$ hours of relaxation $\rightarrow 6$ hour of filtration $\rightarrow 15$ hours of relaxation $\rightarrow 6$ hour of filtration. Between the runs the membrane was cleaned by surface rinsing or osmotic backwash using water (cleaning was applied in the end of the $1^{\text {st }}$ run, i.e. after 18 hours of filtration). Water was applied to the membrane for $10 \mathrm{~min}$ at a 6 $\mathrm{cm} / \mathrm{s}$ cross-flow velocity in the surface-rinsing mode. For the osmotic backwash, the draw solution was placed in front of the active layer, and water was placed in front of the support layer. The draw and feed solutions were pumped for $10 \mathrm{~min}$ at a $1.5 \mathrm{~cm} / \mathrm{s}$ cross-flow velocity. In addition to the surface rinsing and osmotic backwash one more water flux recovery approach was applied, i.e. increase of cross-flow velocity in the second run up to $6 \mathrm{~cm} / \mathrm{s}$. The effect of 
different cleaning strategies was investigated on three membranes. In the end of the $1^{\text {st }}$ run surface rinsing or osmotic backwash or increase of cross-flow velocity was applied.

\subsection{Characterization of silver nanoparticles and the membrane}

The zeta potential and size of the colloids were assessed by Malvern Zetasizer Nano ZS (Malvern Panalytical, UK). The charge of the membranes was determined by a SurPASS electrokinetic analyser (Anton Paar GmbH, AT). A 10 mM potassium chloride (Fisher Scientific, UK) solution and an adjustable-gap sample holder were employed. Potassium hydroxide (SigmaAldrich, USA) and hydrochloric acid (Sigma-Aldrich, USA) were utilized for $\mathrm{pH}$ adjustment. To assess the hydrophilicity of the membrane, the contact-angle method was used; here, a water drop was placed onto the membrane surface using a syringe. Consequently, the air-water-surface contact angle was measured within $10 \mathrm{~s}$ after the deposition of the drop. A Cary 660 FTIR spectrometer (Agilent Technologies, USA) was used for ATR-FTIR analysis. Imaging of the samples was performed by a JEOL JEM 1400 Plus Transmission Electron Microscope (TEM) (JEOL USA, Inc., USA). Atomic Force Microscope (AFM) analysis was performed with a SmartSPM 1000 system (AIST-NT Inc., USA). A Rigaku SmartLab (Rigaku, JP) apparatus was used to obtain X-Ray Diffraction (XRD) spectra. The applied diffraction angle (20) ranged between $10-80^{\circ}$. The antimicrobial activity of the pristine and modified membranes was assessed as follows. E. coli cells were cultured by the inoculation of lysogeny broth (LB) media (Sigma-Aldrich, USA) with E. coli cells, followed by an incubation at $37^{\circ} \mathrm{C}$ for $16-18$ hours. Subsequently, $100 \mu \mathrm{l}$ of the culture solution was spread on LB agar (Sigma-Aldrich, USA). Equal portions of the original and modified membranes were placed onto the agar (where E. coli was spread) while the support layer of the membrane was facing air. The colony-forming units beneath the membrane samples were examined after an overnight incubation at $37{ }^{\circ} \mathrm{C}$. The activity of the aquaporin channels was analysed in the $\mathrm{FO}$ mode, with a $12 \mathrm{~cm} / \mathrm{s}$ cross-flow velocity, 5/12 LMH initial water flux, counter-current direction of the feed and draw solutions, 

water flux. It is because the high flow may potentially remove silver nanoparticles from the

232 membrane and as result the membrane structure will be affected.

233

234 All experiments mentioned in the materials and methods section were repeated at least two 235 times. Table 2 is summarizing operation conditions of all FO experiments.

Table 2. FO experiments' operation conditions.

\begin{tabular}{|c|c|c|c|c|c|c|c|c|c|c|}
\hline \multirow[t]{2}{*}{ Experiment } & \multirow[t]{2}{*}{$\begin{array}{l}\text { solution/initial } \\
\text { water flux in } \\
\text { LMH LMH }\end{array}$} & & Fee & soluti & & & $\begin{array}{l}\text { Cross- } \\
\text { flow } \\
\text { velocity } \\
\text { of draw } \\
\text { solution, } \\
\mathrm{cm} / \mathrm{s}\end{array}$ & $\begin{array}{l}\text { Cross- } \\
\text { flow } \\
\text { velocity } \\
\text { of feed } \\
\text { solution, } \\
\mathrm{cm} / \mathrm{s}\end{array}$ & $\begin{array}{l}\text { Experimental } \\
\text { time, hours }\end{array}$ & $\begin{array}{l}\text { Spacer } \\
\text { type }\end{array}$ \\
\hline & & $\mathrm{NaCl}$ & $\mathrm{CaCl}_{2}$ & ALG & $\mathrm{TA}$ & BSA & & & & \\
\hline \multirow[t]{4}{*}{ Figure $3 a$} & $\mathrm{NaCl} / 18$ & $\begin{array}{c}10 \\
\mathrm{mM}\end{array}$ & $\begin{array}{c}10 \\
\mathrm{mM}\end{array}$ & & & & 12.5 & 12.5 & 6 & $\begin{array}{c}47 \\
\text { diamond }\end{array}$ \\
\hline & $\mathrm{NaCl} / 18$ & $\begin{array}{c}10 \\
\mathrm{mM}\end{array}$ & $\begin{array}{c}10 \\
\mathrm{mM}\end{array}$ & $\begin{array}{l}100 \\
\mathrm{mg} / \mathrm{l}\end{array}$ & & & 12.5 & 12.5 & 6 & $\begin{array}{c}47 \\
\text { diamond }\end{array}$ \\
\hline & $\mathrm{NaCl} / 18$ & $\begin{array}{c}10 \\
\mathrm{mM}\end{array}$ & $\begin{array}{c}10 \\
\mathrm{mM}\end{array}$ & & $\begin{array}{r}100 \\
\mathrm{mg} / \mathrm{l}\end{array}$ & & 12.5 & 12.5 & 6 & $\begin{array}{c}47 \\
\text { diamond }\end{array}$ \\
\hline & $\mathrm{NaCl} / 18$ & $\begin{array}{c}10 \\
\mathrm{mM}\end{array}$ & $\begin{array}{c}10 \\
\mathrm{mM}\end{array}$ & & & $\begin{array}{l}100 \\
\mathrm{mg} / \mathrm{l}\end{array}$ & 12.5 & 12.5 & 6 & $\begin{array}{c}47 \\
\text { diamond }\end{array}$ \\
\hline \multirow[t]{2}{*}{ Figure $3 b$} & $\mathrm{NaCl} / 18$ & $\begin{array}{c}10 \\
\mathrm{mM}\end{array}$ & $\begin{array}{c}10 \\
\mathrm{mM}\end{array}$ & $\begin{array}{l}100 \\
\mathrm{mg} / \mathrm{l}\end{array}$ & $\begin{array}{r}100 \\
\mathrm{mg} / \mathrm{l}\end{array}$ & & 12.5 & 12.5 & 6 & $\begin{array}{c}47 \\
\text { diamond }\end{array}$ \\
\hline & $\mathrm{NaCl} / 18$ & $\begin{array}{c}10 \\
\mathrm{mM}\end{array}$ & $\begin{array}{c}10 \\
\mathrm{mM}\end{array}$ & $\begin{array}{l}100 \\
\mathrm{mg} / \mathrm{l}\end{array}$ & & $\begin{array}{l}100 \\
\mathrm{mg} / \mathrm{l}\end{array}$ & 12.5 & 12.5 & 6 & $\begin{array}{c}47 \\
\text { diamond }\end{array}$ \\
\hline
\end{tabular}




\begin{tabular}{|c|c|c|c|c|c|c|c|c|c|c|}
\hline & $\mathrm{NaCl} / 18$ & $\begin{array}{c}10 \\
\mathrm{mM}\end{array}$ & $\begin{array}{c}10 \\
\mathrm{mM}\end{array}$ & & $\begin{array}{r}100 \\
\mathrm{mg} / \mathrm{l}\end{array}$ & $\begin{array}{r}100 \\
\mathrm{mg} / \mathrm{l}\end{array}$ & 12.5 & 12.5 & 6 & $\begin{array}{c}47 \\
\text { diamond }\end{array}$ \\
\hline & $\mathrm{NaCl} / 18$ & $\begin{array}{c}10 \\
\mathrm{mM}\end{array}$ & $\begin{array}{c}10 \\
\mathrm{mM}\end{array}$ & $\begin{array}{r}100 \\
\mathrm{mg} / \mathrm{l}\end{array}$ & $\begin{array}{c}100 \\
\mathrm{mg} / \mathrm{l}\end{array}$ & $\begin{array}{r}100 \\
\mathrm{mg} / \mathrm{l}\end{array}$ & 12.5 & 12.5 & 6 & $\begin{array}{c}47 \\
\text { diamond }\end{array}$ \\
\hline Figure $4 a$ & $\mathrm{NaCl} / 18$ & & $\begin{array}{c}10 \\
\mathrm{mM}\end{array}$ & $\begin{array}{r}100 \\
\mathrm{mg} / \mathrm{l}\end{array}$ & $\begin{array}{c}100 \\
\mathrm{mg} / \mathrm{l}\end{array}$ & $\begin{array}{r}100 \\
\mathrm{mg} / \mathrm{l}\end{array}$ & 12.5 & 12.5 & 6 & $\begin{array}{c}47 \\
\text { diamond }\end{array}$ \\
\hline & $\mathrm{NaCl} / 18$ & $\begin{array}{c}10 \\
\mathrm{mM}\end{array}$ & $\begin{array}{c}10 \\
\mathrm{mM}\end{array}$ & $\begin{array}{r}100 \\
\mathrm{mg} / \mathrm{l}\end{array}$ & $\begin{array}{c}100 \\
\mathrm{mg} / \mathrm{l}\end{array}$ & $\begin{array}{r}100 \\
\mathrm{mg} / \mathrm{l}\end{array}$ & 12.5 & 12.5 & 6 & $\begin{array}{c}47 \\
\text { diamond }\end{array}$ \\
\hline & $\mathrm{NaCl} / 18$ & $\begin{array}{l}100 \\
\mathrm{mM}\end{array}$ & $\begin{array}{c}10 \\
\mathrm{mM}\end{array}$ & $\begin{array}{r}100 \\
\mathrm{mg} / \mathrm{l}\end{array}$ & $\begin{array}{c}100 \\
\mathrm{mg} / \mathrm{l}\end{array}$ & $\begin{array}{r}100 \\
\mathrm{mg} / \mathrm{l}\end{array}$ & 12.5 & 12.5 & 6 & $\begin{array}{c}47 \\
\text { diamond }\end{array}$ \\
\hline Figure $4 b$ & $\mathrm{NaCl} / 18$ & $\begin{array}{c}10 \\
\mathrm{mM}\end{array}$ & & $\begin{array}{r}100 \\
\mathrm{mg} / \mathrm{l}\end{array}$ & $\begin{array}{c}100 \\
\mathrm{mg} / \mathrm{l}\end{array}$ & $\begin{array}{r}100 \\
\mathrm{mg} / \mathrm{l}\end{array}$ & 12.5 & 12.5 & 6 & $\begin{array}{c}47 \\
\text { diamond }\end{array}$ \\
\hline & $\mathrm{NaCl} / 18$ & $\begin{array}{c}10 \\
\mathrm{mM}\end{array}$ & $\begin{array}{c}10 \\
\mathrm{mM}\end{array}$ & $\begin{array}{r}100 \\
\mathrm{mg} / \mathrm{l}\end{array}$ & $\begin{array}{c}100 \\
\mathrm{mg} / \mathrm{l}\end{array}$ & $\begin{array}{r}100 \\
\mathrm{mg} / \mathrm{l}\end{array}$ & 12.5 & 12.5 & 6 & $\begin{array}{c}47 \\
\text { diamond }\end{array}$ \\
\hline & $\mathrm{NaCl} / 18$ & $\begin{array}{c}10 \\
\mathrm{mM}\end{array}$ & $\begin{array}{r}30 \\
\mathrm{mM}\end{array}$ & $\begin{array}{r}100 \\
\mathrm{mg} / \mathrm{l}\end{array}$ & $\begin{array}{r}100 \\
\mathrm{mg} / \mathrm{l}\end{array}$ & $\begin{array}{r}100 \\
\mathrm{mg} / \mathrm{l}\end{array}$ & 12.5 & 12.5 & 6 & $\begin{array}{c}47 \\
\text { diamond }\end{array}$ \\
\hline & $\mathrm{NaCl} / 18$ & $\begin{array}{c}10 \\
\mathrm{mM}\end{array}$ & $\begin{array}{l}100 \\
\mathrm{mM}\end{array}$ & $\begin{array}{r}100 \\
\mathrm{mg} / \mathrm{l}\end{array}$ & $\begin{array}{r}100 \\
\mathrm{mg} / \mathrm{l}\end{array}$ & $\begin{array}{r}100 \\
\mathrm{mg} / \mathrm{l}\end{array}$ & 12.5 & 12.5 & 6 & $\begin{array}{c}47 \\
\text { diamond }\end{array}$ \\
\hline Figure 5 & $\mathrm{NaCl} / 18$ & $\begin{array}{c}10 \\
\mathrm{mM}\end{array}$ & $\begin{array}{c}10 \\
\mathrm{mM}\end{array}$ & $\begin{array}{r}100 \\
\mathrm{mg} / \mathrm{l}\end{array}$ & $\begin{array}{c}100 \\
\mathrm{mg} / \mathrm{l}\end{array}$ & $\begin{array}{r}100 \\
\mathrm{mg} / \mathrm{l}\end{array}$ & 12.5 & 12.5 & 6 & \\
\hline & $\mathrm{NaCl} / 18$ & $\begin{array}{c}10 \\
\mathrm{mM}\end{array}$ & $\begin{array}{c}10 \\
\mathrm{mM}\end{array}$ & $\begin{array}{r}100 \\
\mathrm{mg} / \mathrm{l}\end{array}$ & $\begin{array}{c}100 \\
\mathrm{mg} / \mathrm{l}\end{array}$ & $\begin{array}{r}100 \\
\mathrm{mg} / \mathrm{l}\end{array}$ & 12.5 & 12.5 & 6 & $\begin{array}{c}47 \\
\text { parallel }\end{array}$ \\
\hline & $\mathrm{NaCl} / 18$ & $\begin{array}{c}10 \\
\mathrm{mM}\end{array}$ & $\begin{array}{c}10 \\
\mathrm{mM}\end{array}$ & $\begin{array}{r}100 \\
\mathrm{mg} / \mathrm{l}\end{array}$ & $\begin{array}{c}100 \\
\mathrm{mg} / \mathrm{l}\end{array}$ & $\begin{array}{r}100 \\
\mathrm{mg} / \mathrm{l}\end{array}$ & 12.5 & 12.5 & 6 & $\begin{array}{c}17 \\
\text { diamond }\end{array}$ \\
\hline & $\mathrm{NaCl} / 18$ & 10 & 10 & 100 & 100 & 100 & 12.5 & 12.5 & 6 & 47 \\
\hline
\end{tabular}




\begin{tabular}{|c|c|c|c|c|c|c|c|c|c|c|}
\hline & & $\mathrm{mM}$ & $\mathrm{mM}$ & $\mathrm{mg} / \mathrm{l}$ & $\mathrm{mg} / \mathrm{l}$ & $\mathrm{mg} / \mathrm{l}$ & & & & diamond \\
\hline Figure 6 & $\mathrm{NaCl} / 7$ & $\begin{array}{c}10 \\
\mathrm{mM}\end{array}$ & $\begin{array}{c}10 \\
\mathrm{mM}\end{array}$ & $\begin{array}{r}100 \\
\mathrm{mg} / 1\end{array}$ & $\begin{array}{r}100 \\
\mathrm{mg} / 1\end{array}$ & $\begin{array}{r}100 \\
\mathrm{mg} / 1\end{array}$ & 1.5 & 1.5 & 24 & $\begin{array}{c}47 \\
\text { diamond }\end{array}$ \\
\hline Figure 7 & $\mathrm{NaCl} / 7$ & $\begin{array}{c}10 \\
\mathrm{mM}\end{array}$ & $\begin{array}{c}10 \\
\mathrm{mM}\end{array}$ & $\begin{array}{l}100 \\
\mathrm{mg} / 1\end{array}$ & $\begin{array}{r}100 \\
\mathrm{mg} / 1\end{array}$ & $\begin{array}{l}100 \\
\mathrm{mg} / 1\end{array}$ & 1.5 & 1.5 & 24 & $\begin{array}{c}47 \\
\text { diamond }\end{array}$ \\
\hline Figure 14 & $\mathrm{NaCl} / 5$ & $\begin{array}{c}10 \\
\mathrm{mM}\end{array}$ & $\begin{array}{c}10 \\
\mathrm{mM}\end{array}$ & & & & 12 & 12 & 6 & $\begin{array}{c}47 \\
\text { diamond }\end{array}$ \\
\hline & $\mathrm{NaCl} / 12$ & $\begin{array}{c}10 \\
\mathrm{mM}\end{array}$ & $\begin{array}{c}10 \\
\mathrm{mM}\end{array}$ & & & & 12 & 12 & 6 & $\begin{array}{c}47 \\
\text { diamond }\end{array}$ \\
\hline
\end{tabular}

237

238 3. Results and discussion

$239 \quad 3.1$ Complex organic fouling

240 Figure 3(a) illustrates the FO membrane fouling by individual ALG, TA, and BSA. 

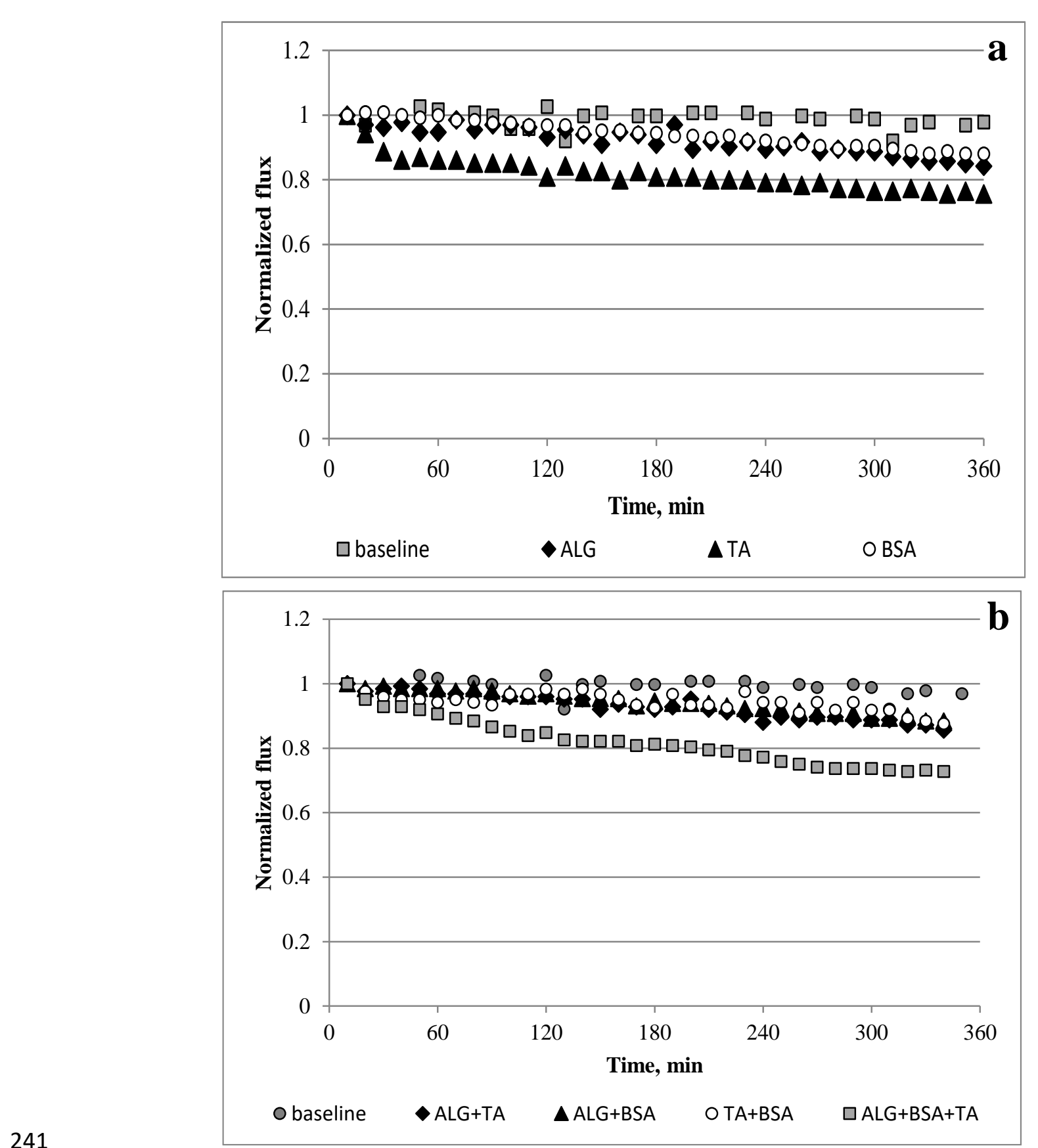

Figure 3. Normalized water flux for: a) baseline experiment and mono-component fouling solutions; b) di- and tri-component fouling solutions. The feed solutions contained $100 \mathrm{mg} / \mathrm{l}$ ALG, $100 \mathrm{mg} / 1 \mathrm{TA}, 100 \mathrm{mg} / \mathrm{l} \mathrm{BSA}, 10 \mathrm{mM} \mathrm{NaCl}, 10 \mathrm{mM} \mathrm{CaCl} 2$. Standard deviation for the experiments presented at the figure is negligible.

The graph displays $24 \%$ water flux decline for TA, 16 and $12 \%$ for ALG and BSA. Adding two

247 foulants into a single feed solution and applying it to the membrane resulted in around $12 \%$ water flux reduction for ALG+TA, ALG+BSA, and TA+BSA (Figure 3(b)). When all three 
249 foulants were added to the feed solution, the experiment showed a $27 \%$ drop in the water flux.

250 The baseline experiment showed a negligible flux decline.

251

252 The effect of the ions' valency and ionic strength on the degree of water flux decline are shown 253 in Figure 4.
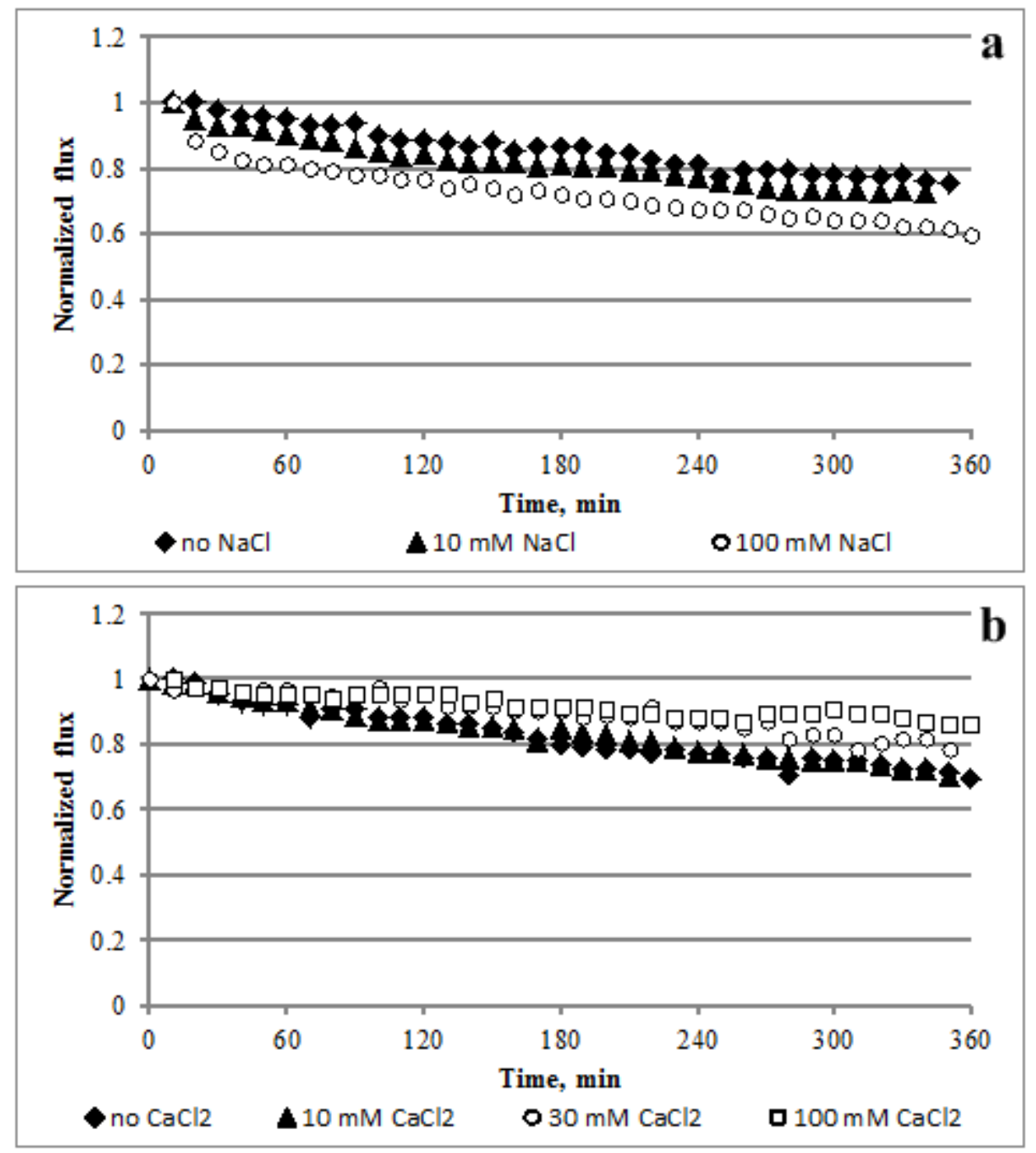

Figure 4. Effect of the ions' valency and salt concentration on the water flux. The feed solutions contained 100 mg/l ALG; 100 mg/l TA; 100 mg/l BSA; 10 or 100 mM NaCl; 10, 30, or 100 mM $\mathrm{CaCl}_{2}$. Standard deviation for the experiments presented at the figure is negligible.

By the end of the experiment, the water flux through the membranes exposed to the 0 and $10 \mathrm{mM} \mathrm{NaCl}$ solutions fell to $75 \%$ and $73 \%$ of the initial values, respectively (Figure 4(a)). After being exposed to the $100 \mathrm{mM}$ solution of $\mathrm{NaCl}$, the water flux through the membrane was 
reduced by $40 \%$. For the various concentrations of calcium chloride, the following results were obtained: $31 \%$ (for $0 \mathrm{mM}$ ), 29\% (for $10 \mathrm{mM}$ ), 21\% (for $30 \mathrm{mM}$ ), and 14\% (for $100 \mathrm{mM}$ ) (Figure 4(b)).

The influence of the application of various spacers to the feed side of the membrane is illustrated in Figure 5. The FO experiment conducted without a spacer led to an $11 \%$ drop in water flux. Applying the 47 parallel, 47 diamond, and 17 diamond spacers resulted in a 21\%, 29\%, and $31 \%$ water flux reduction, respectively.

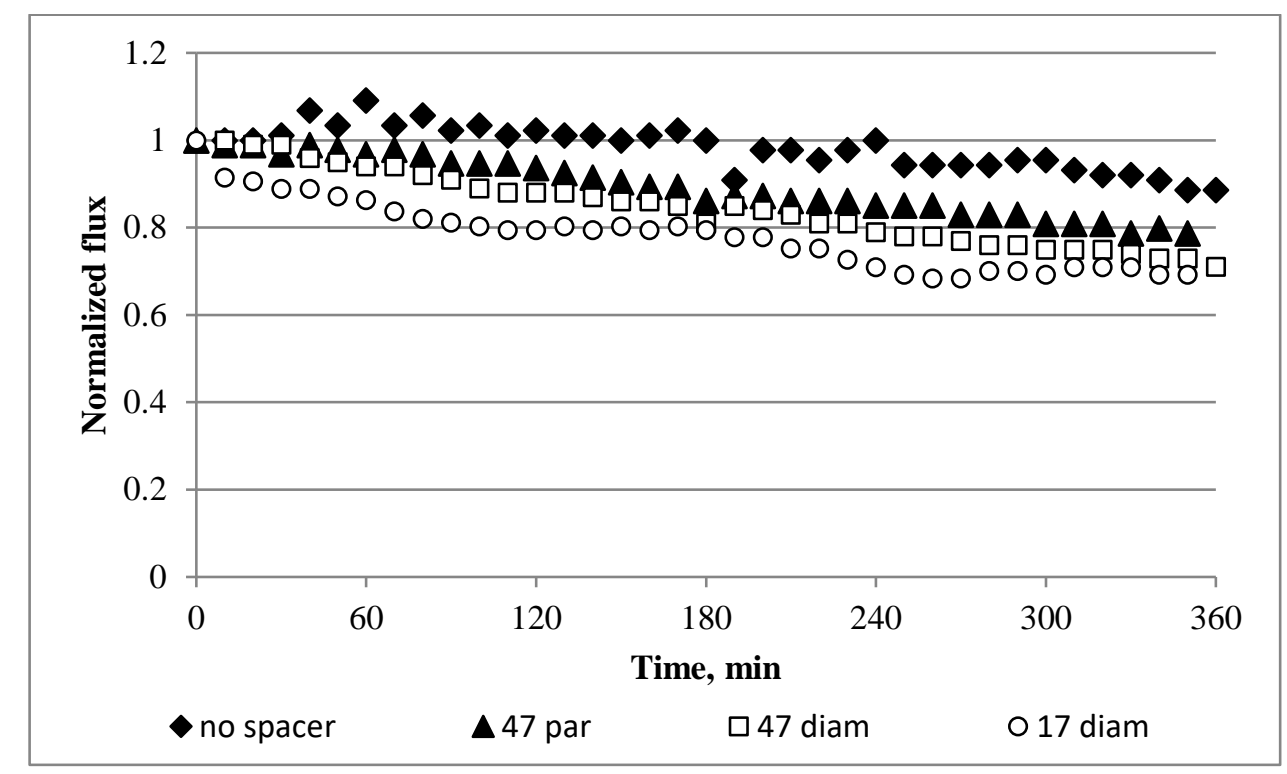

Figure 5. Effect of the spacers on the water flux. The feed solutions contained $100 \mathrm{mg} / \mathrm{l}$ ALG, $100 \mathrm{mg} / \mathrm{TA}, 100 \mathrm{mg} / \mathrm{BSA}, 10 \mathrm{mM} \mathrm{NaCl}, 10 \mathrm{mM} \mathrm{CaCl}_{2}$. Standard deviation for the experiments presented at the figure is negligible.

\subsection{Fouling and cleaning in the absence/presence of silver nanoparticles}

Figures 6 and 7 show the performance of the pristine and modified membranes. 


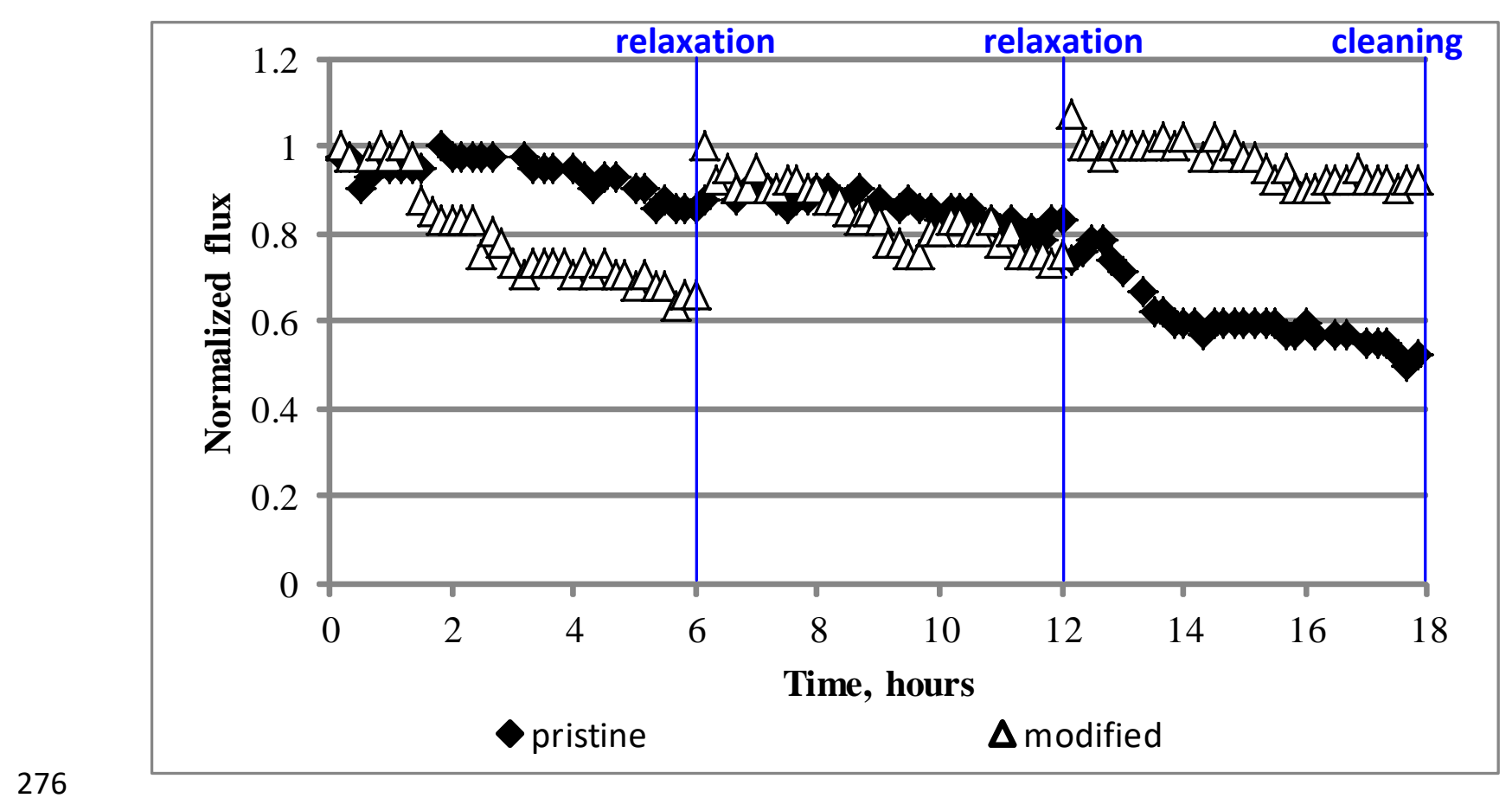

277 Figure 6. Water flux through the pristine and modified membranes during the $1^{\text {st }}$ filtration run.

278 The feed solutions contained 100 mg/l ALG, 100 mg/l TA, 100 mg/l BSA, 10 mM NaCl, 10 mM

$279 \mathrm{CaCl}_{2}$. Standard deviation for the experiments presented at the figure is negligible. 

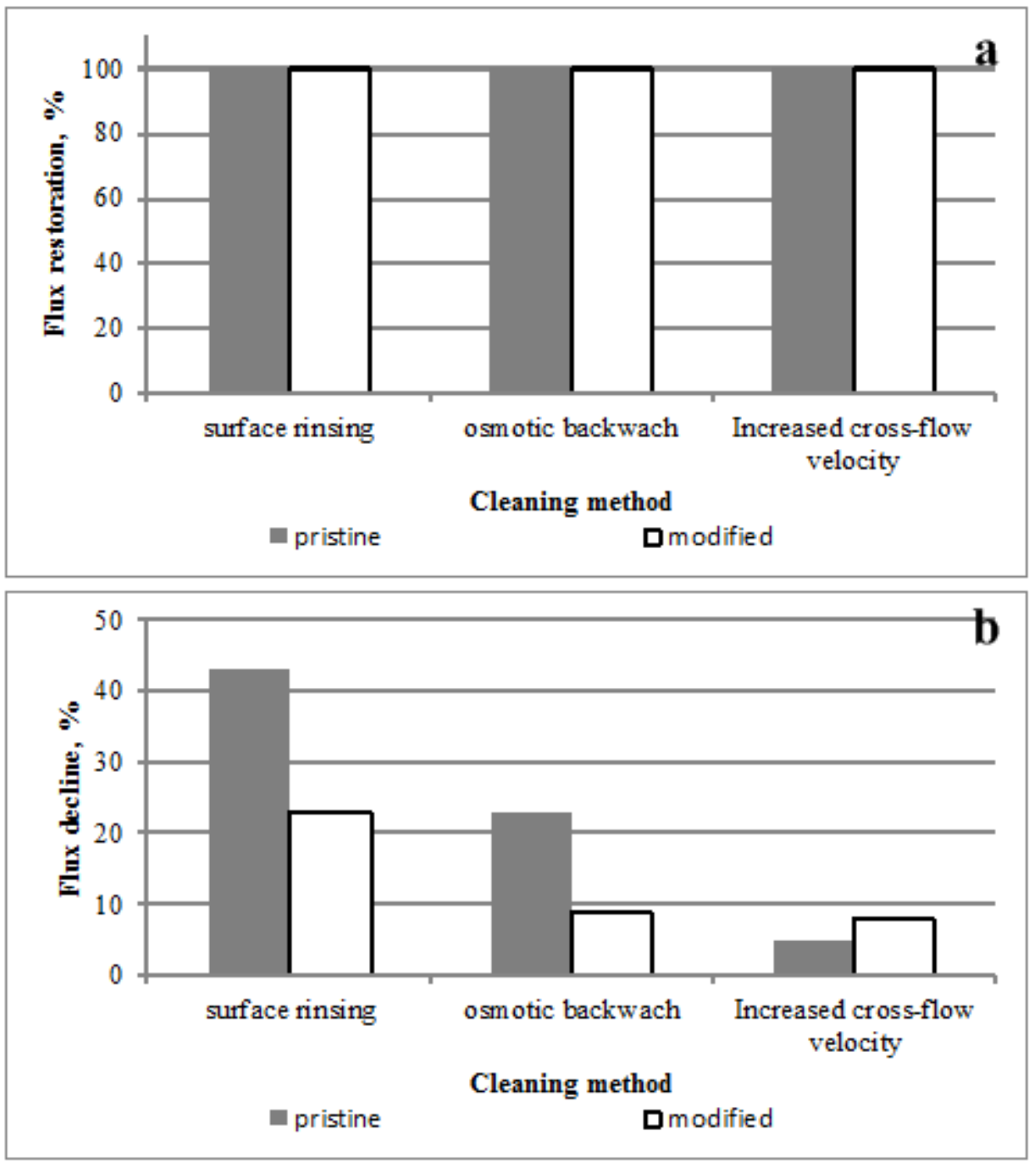

Figure 7. Performance of the pristine and modified membranes: a) flux restoration after the $1^{\text {st }}$ filtration run and subsequent cleaning; b) water flux decline at the end of the $2^{\text {nd }}$ filtration run. The feed solutions contained $100 \mathrm{mg} / \mathrm{l}$ ALG, $100 \mathrm{mg} / \mathrm{l} \mathrm{TA}, 100 \mathrm{mg} / \mathrm{l} \mathrm{BSA}, 10 \mathrm{mM} \mathrm{NaCl}, 10 \mathrm{mM}$ $\mathrm{CaCl}_{2}$. Standard deviation for the experiments presented at the figure is negligible.

As mentioned in the materials and methods (section 2.0), the membranes were fouled in the filtration/relaxation regime. During the first $6 \mathrm{~h}(0-6 \mathrm{~h}$ time interval), the pristine membrane demonstrated better performance than the modified one. In the 6-12 and 12-18 h time intervals, the treated membrane showed better performance than the pristine membrane. After the relaxation mode, the water flux of the modified membranes was restored to their initial value. On the contrary, the fouling of the pristine membrane gradually worsened. All membranes-both the pristine and the modified-exhibited a $100 \%$ flux restoration after the first filtration run and 
292

293

294

295

296

297

298

299

300

301

302

303

304

305

306

subsequent cleaning. The pristine and modified membranes that were exposed to surface rinsing showed a $40 \%$ and $21 \%$ water flux decline, respectively. The application of osmotic backwash to the pristine and modified membranes resulted in a $23 \%$ and $7 \%$ water flux decline. The increase of the cross-flow velocity (during the second run) achieved a negligible water flux decline for both membranes.

\subsection{Influence of silver nanoparticles on the membrane properties}

FTIR spectra of the pristine membrane are shown in Figure 8 with the most significant peaks marked. Earlier reports claimed that the first five peaks (listed in Table 3) belong to polyamide, while the rest originate from polyethersulfone [9, 21, 33, 34].

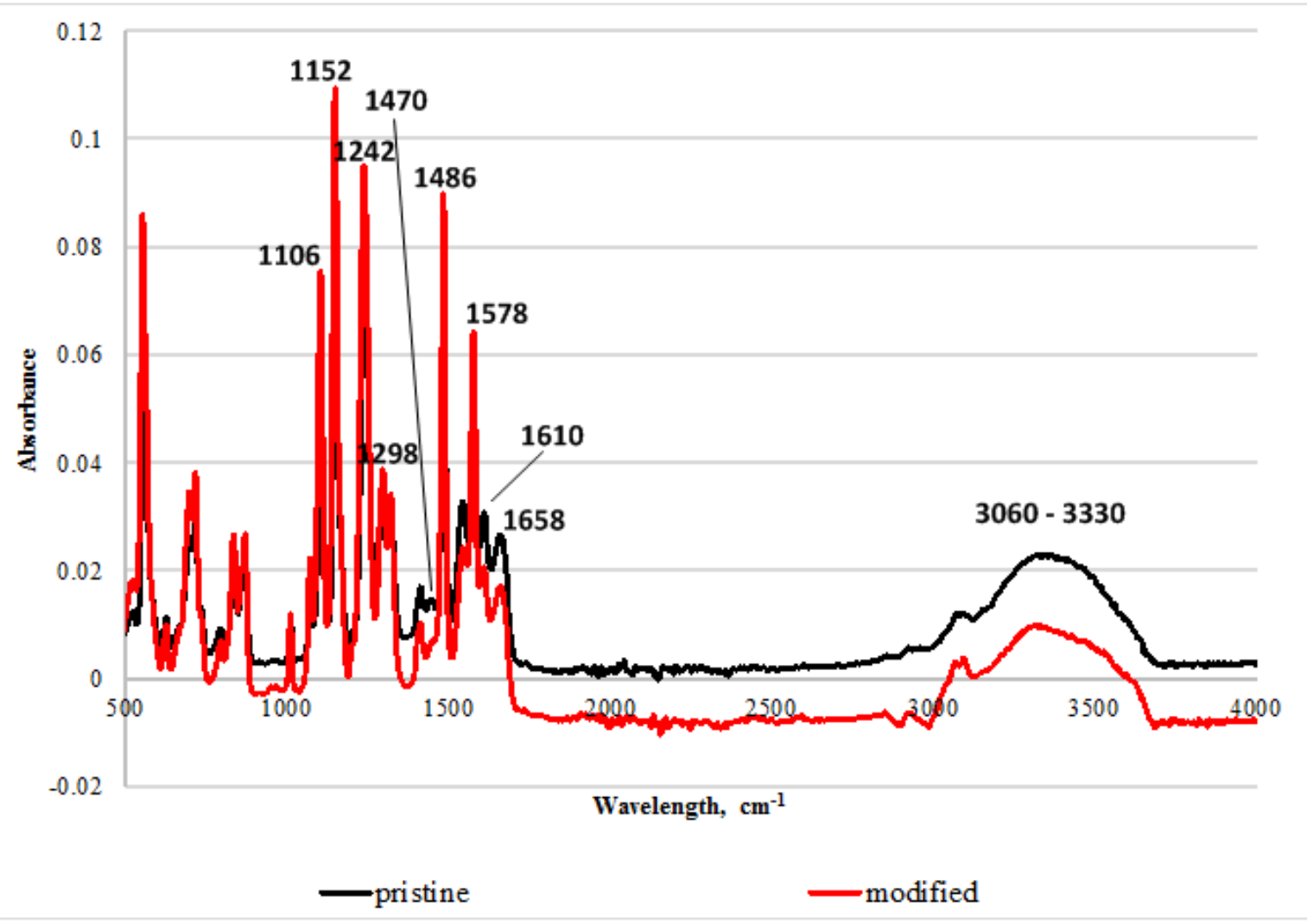

Figure 8. ATR-FTR spectra of the membrane. Standard deviation for the experiments presented at the figure is negligible.

Table 3. Assignment of relevant IR absorption bands to the aquaporin FO membrane spectra. 


\begin{tabular}{|c|c|}
\hline Frequency, $1 / \mathrm{cm}$ & Spectra assignment \\
\hline \multicolumn{2}{|r|}{ Polyamide } \\
\hline 1470 & $\mathrm{C}=\mathrm{O}$ stretching; $\mathrm{O}-\mathrm{H}$ bending \\
\hline 1578 & $\mathrm{C}-\mathrm{N}$ stretching, amide II \\
\hline 1610 & $(-\mathrm{N}-\mathrm{H})$ stretching \\
\hline 1658 & $\mathrm{C}=\mathrm{O}$ stretching, amide $\mathrm{I}$ \\
\hline $3330-3060$ & $\mathrm{~N}-\mathrm{H}$ stretching vibration \\
\hline \multicolumn{2}{|r|}{ Polyethersulfone } \\
\hline 1106 & skeletal aliphatic $\mathrm{C}-\mathrm{C} /$ aromatic hydrogen bending/rocking \\
\hline 1152 & $\mathrm{SO}_{2}$, symmetric stretch \\
\hline 1242 & aryl-O-aryl, $\mathrm{C}-\mathrm{O}$ stretch \\
\hline 1298 & $\mathrm{SO}_{2}$, asymmetric stretch \\
\hline 1486 & $\mathrm{SO}_{2}$, asymmetric stretch \\
\hline
\end{tabular}

308 Comparing the pristine and modified membranes, the $1470 \mathrm{~cm}^{-1}$ peak exhibits a clear 309 suppression in the treated membrane. The results of the zeta potential measurements (Figure 9) 310 show that after the modification, the membranes became more electropositive. For the pristine 311 membrane the zeta potential changed from $+14.8 \mathrm{mV}(\mathrm{pH} 2)$ to $-42.1 \mathrm{mV}(\mathrm{pH} 11)$ and for the 312 modified membrane from $+7.6 \mathrm{mV}(\mathrm{pH} 2)$ to $-29.06 \mathrm{mV}(\mathrm{pH} 11)$. 


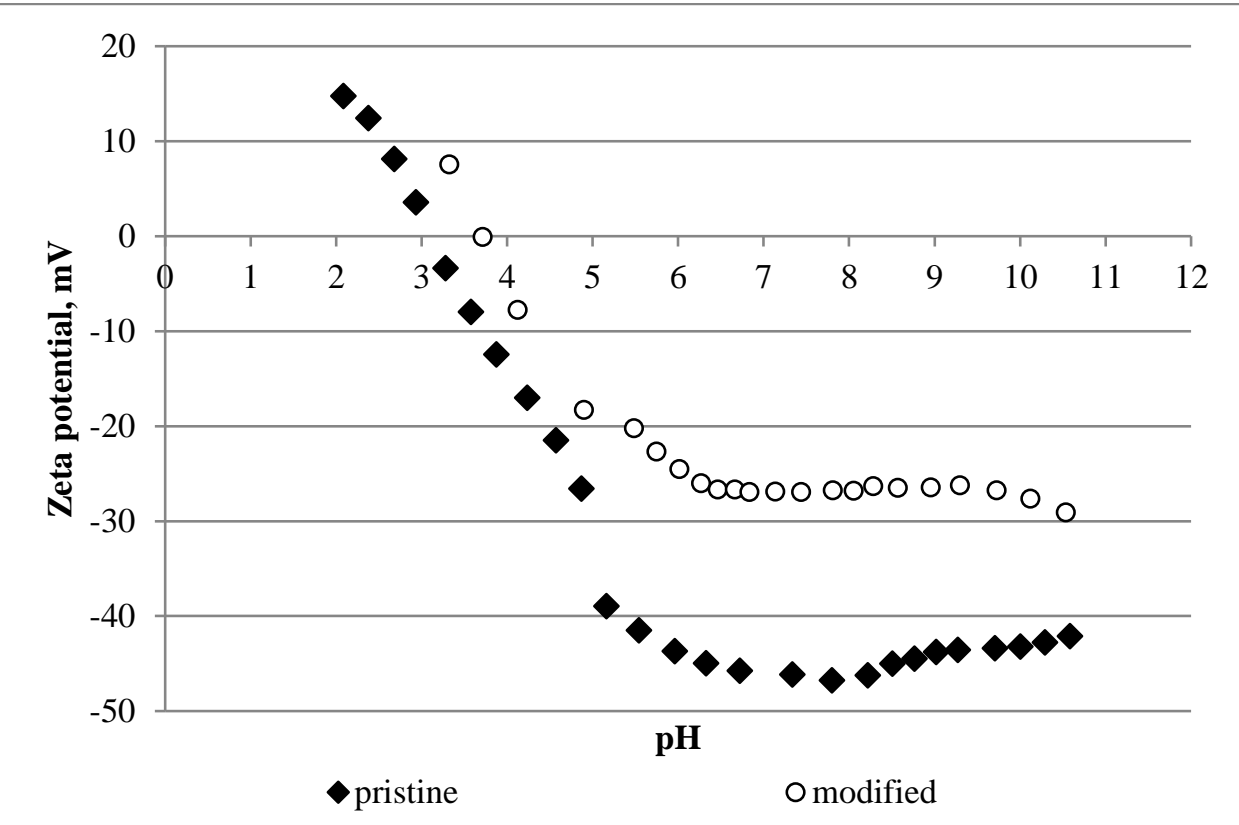

Figure 9. Zeta potential as a function of the $\mathrm{pH}$ for the pristine and modified membranes.

Standard deviation for the experiments presented at the figure is negligible.

By testing the membranes' hydrophilicity, it was found that the contact angle decreased from $53^{\circ}$ to $45^{\circ}$ after the incorporation of the silver nanoparticles. Subsequently, XRD analysis was conducted to determine the phases present of the membranes. The results are presented in Figure 10.

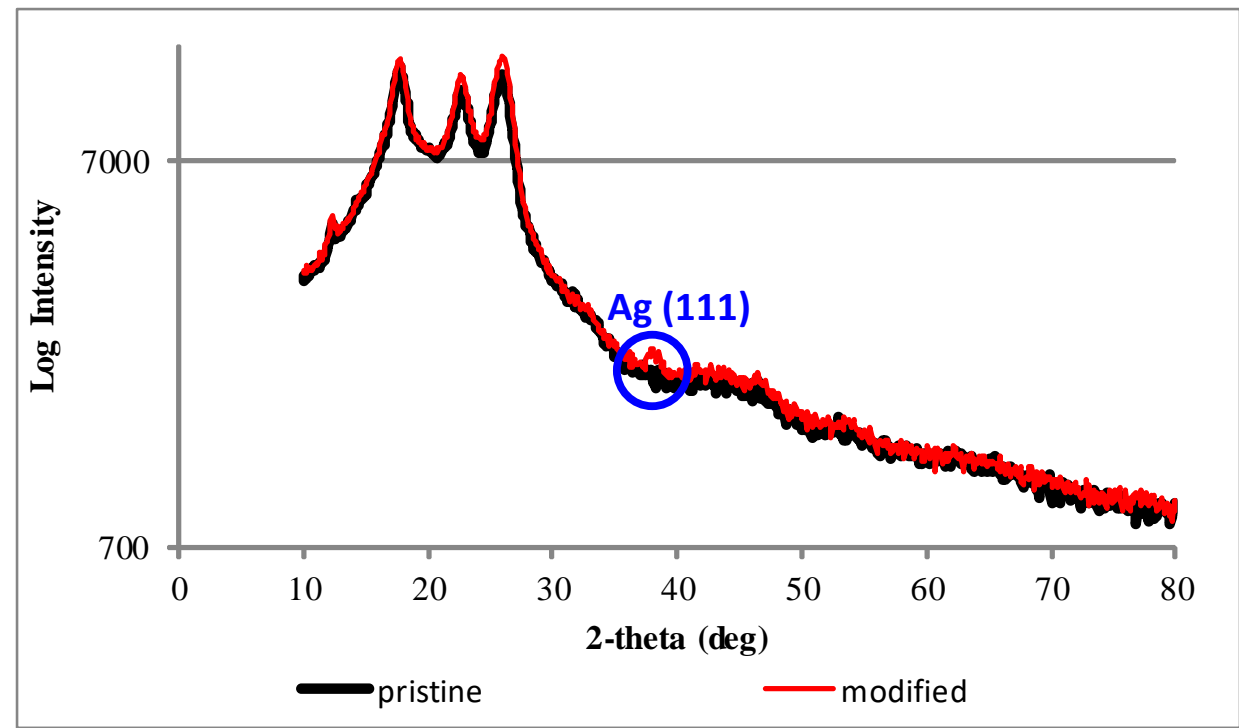

Figure 10. XRD pattern of the pristine and modified membranes. Standard deviation for the experiments presented at the figure is negligible. 
Both membranes displayed diffraction peaks at $12^{\circ}, 18^{\circ}, 23^{\circ}$, and $26^{\circ}$. Moreover, the treated membranes also exhibited a peak at $38^{\circ}$. TEM micrographs (Figure 11) clearly demonstrated the presence of silver nanoparticles on the surface of the treated membranes. AFM images (Figure 12) showed that the original membrane exhibits more pronounced differences between valleys and peaks than the modified membrane. Indeed, it was found that the surface roughness of the pristine and modified membranes are 96 and $56 \mathrm{~nm}$, respectively.

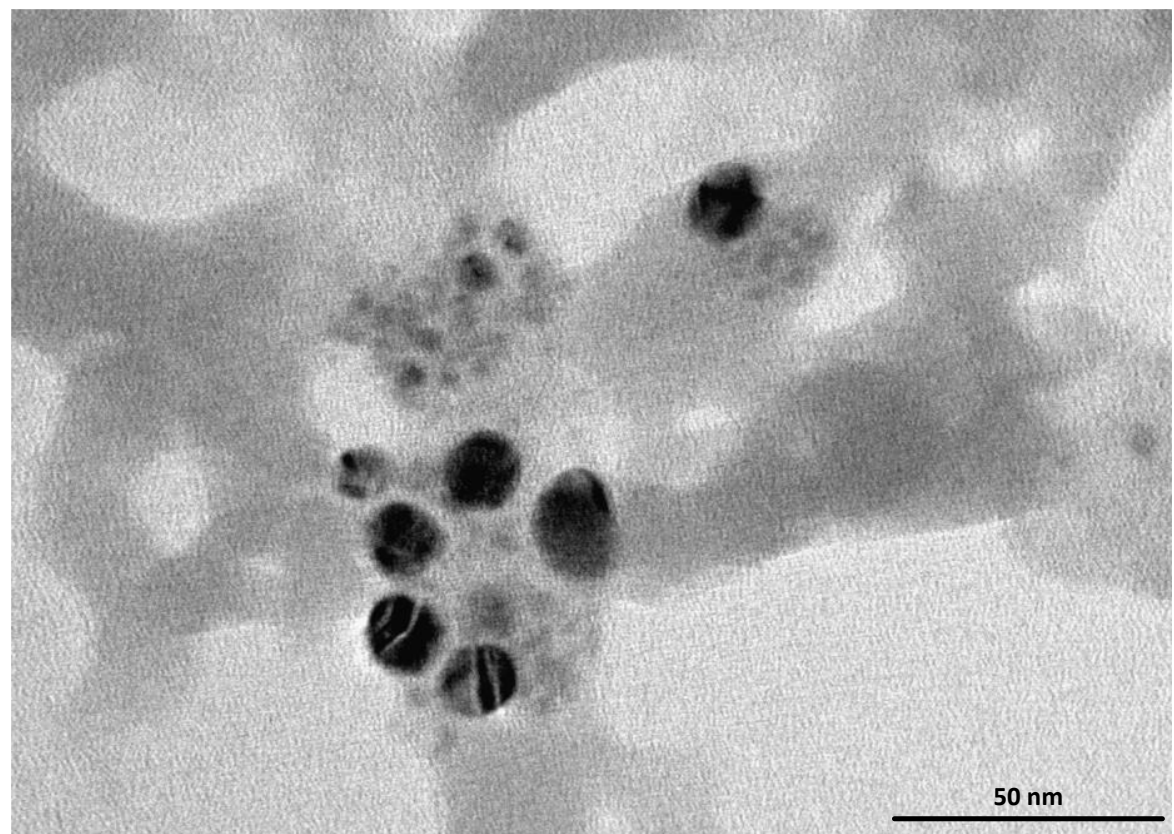

Figure 11. TEM image of silver nanoparticles on the surface of the membrane's active layer. Standard deviation for the experiments presented at the figure is negligible.
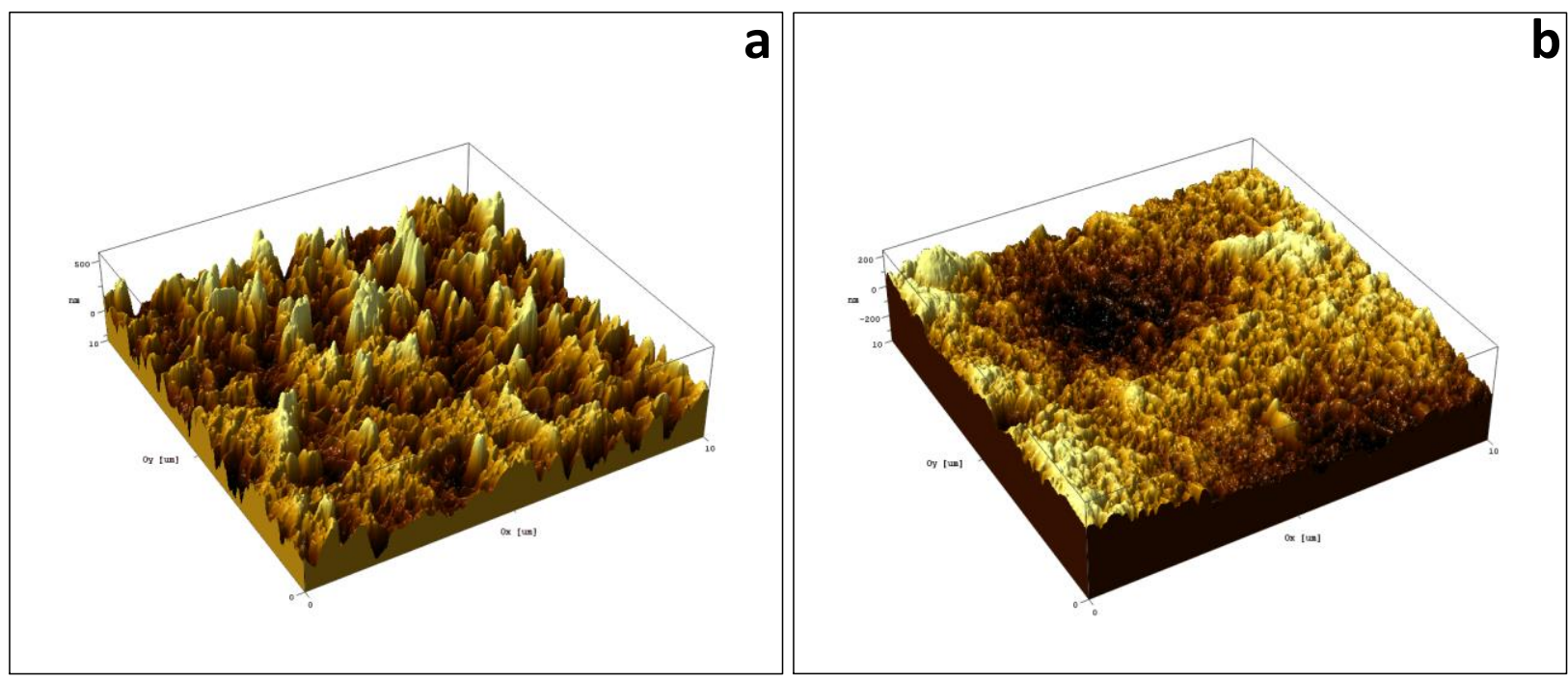

experiments presented at the figure is negligible.

337 Figure 13 presents the results of the antimicrobial tests, which consisted of placing both the 338 pristine and modified membranes on E.coli-cultivating LB agar plates. The area beneath the 339 pristine membranes exhibited bacteria growth, while the modified membrane showed 340 antimicrobial properties, i.e. the area beneath the modified membrane remained clear.
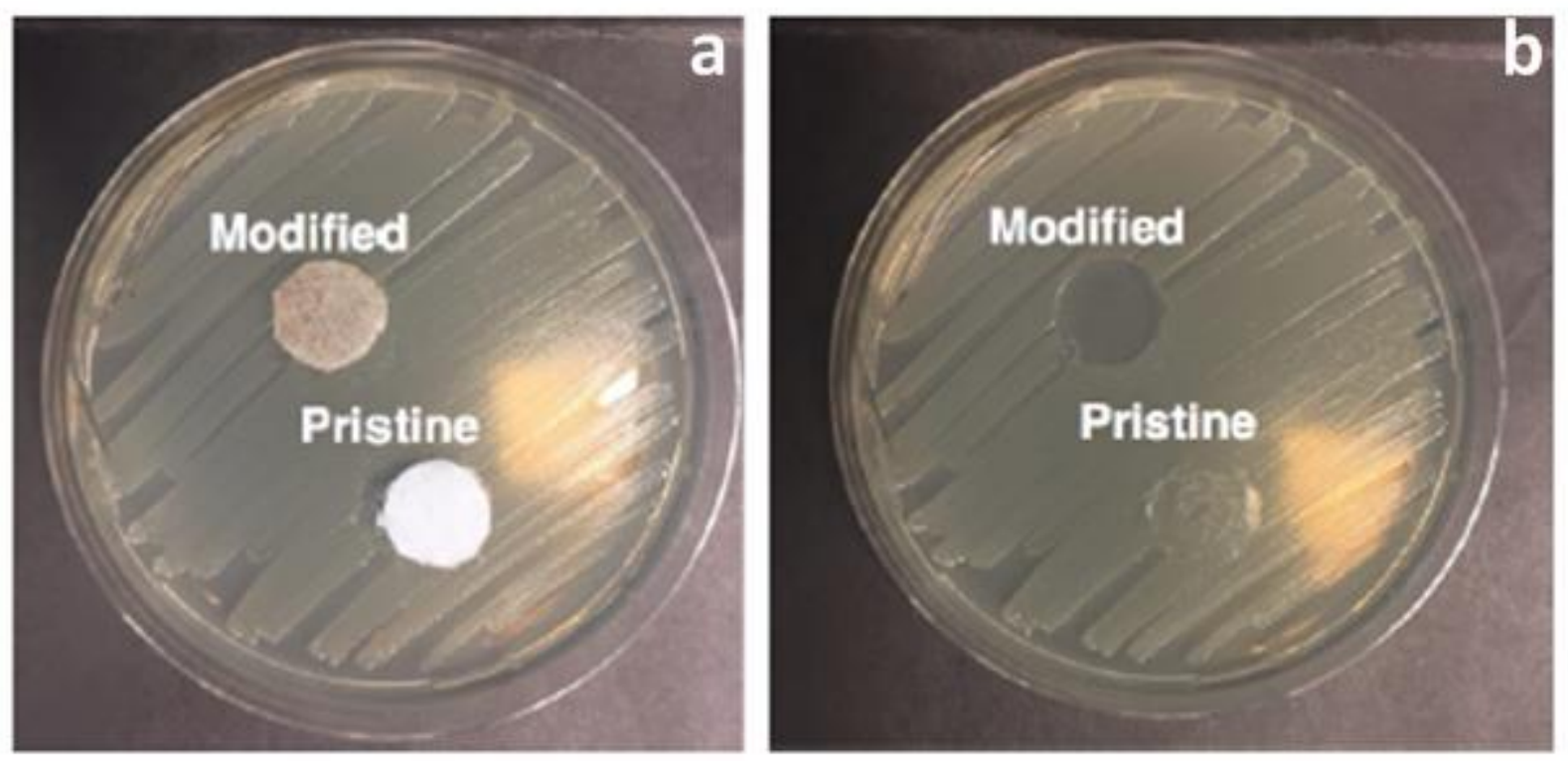

342 Figure 13 . Results of the antimicrobial test: a) before and b) after overnight incubation (at $37{ }^{\circ} \mathrm{C}$ ) 343 of the pristine and modified membranes. Standard deviation for the experiments presented at the figure is negligible.

345 The water flux with the $10 \mathrm{mM} \mathrm{NaCl}$ feed solution through the pristine and the modified membranes is depicted in Figure 14. The experiments were carried out at 5 and 12 LMH initial water fluxes. The water flux through both membranes was stable within $6 \mathrm{~h}$ of filtration and no flux decline was observed. 

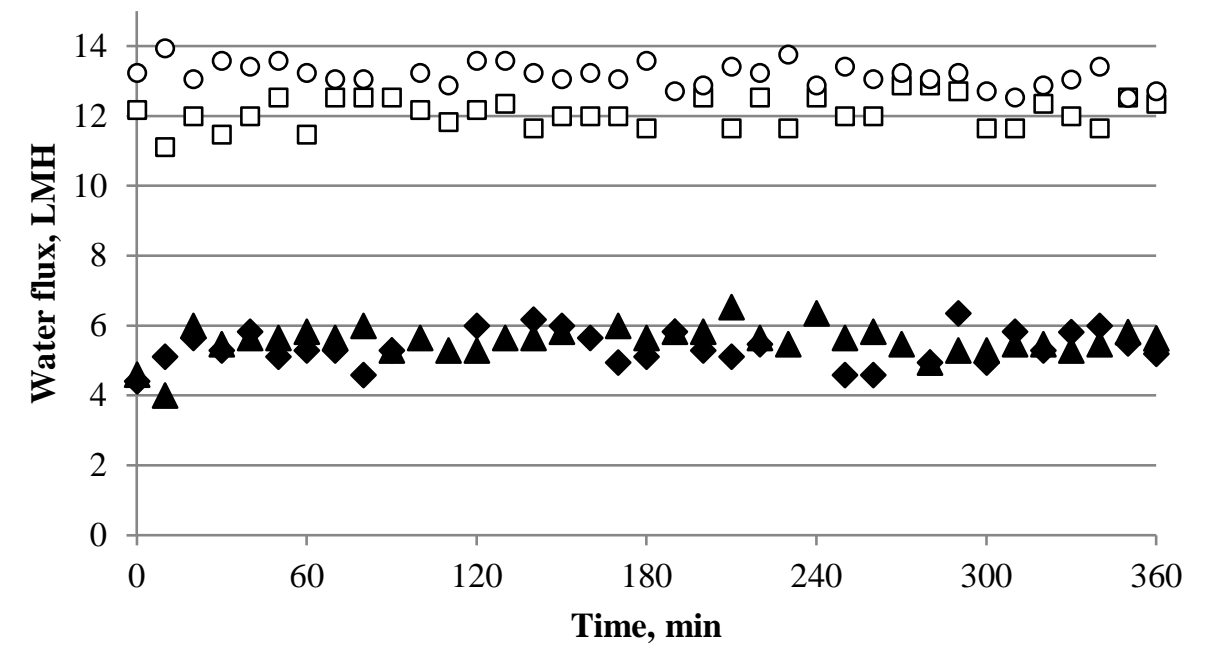

$\checkmark$ baseline pristine $1 \Delta$ baseline modified $1 \square$ baseline pristine 20 baseline modified 2

Figure 14. Feed solution contains $10 \mathrm{mM}$ sodium chloride. Standard deviation for the experiments presented at the figure is negligible.

\subsection{Discussion}

By comparing mono-, di-, and tri-component fouling experiments, the results of the filtration experiments performed with individual ALG, BSA, TA cannot be used accurately predict the water flux decline initiated by the combination of ALG+TA, ALG+BSA, TA+BSA, and ALG+BSA+TA. This suggests the presence of a reaction between the foulants and/or the membrane. Indeed, existing literature claims that tannins interact with proteins and polysaccharides, and, in addition, proteins react with polysaccharides [35, 36]. These interactions may explain why the additive flux concept (water flux decline initiated by foulant $1+$ water flux decline initiated by foulant $2=$ water flux decline initiated by a solution that contains both foulant 1 and foulant 2) cannot be used to predict the degree of fouling caused by multicomponent solutions. It was also found that the presence of salts in the solution affects the interactions between proteins, tannins, and polysaccharides. Increasing $\mathrm{NaCl}$ concentration in the feed solution leads to severe water flux decline [37]. This was observed for sodium chloride in the present study. However, an opposite trend was found for $\mathrm{CaCl}_{2}$. Considering that all three foulants react with each other and that alginate and calcium ions form a highly organized gel 
layer with a structure resembling an egg-box [38], it can be assumed that the complex

369

370

371

372

373

374

375

376

377

378

ALG+BSA+TA structure exhibits an elevated viscosity [37]. Besides, the membrane exhibited better performance when a spacer with higher porosity was applied. Considering the possible explanations of this phenomenon, it can be speculated that higher affinity exists between the spacer and the ALG+BSA+TA complex, than between the complex and the membrane. The spacer serves as an initiator of the fouling, i.e. the spacer attracts foulants, which then start to accumulate on the spacer's surface. An increased volume of voids in the spacer reduces the number of accumulated foulants, and, consequently, increase the water flux.

From the fouling and cleaning experiments performed with the pristine and modified membranes, it can be concluded that the modified membrane in the $1^{\text {st }}$ run partially outperforms the pristine membrane. The more extensive fouling of the modified membrane during the first 6 $\mathrm{h}$ can be explained by electrostatic interactions, i.e. there is a weak repulsion between the less negatively charged membrane $(\sim(-19) \mathrm{mV}$ at $\mathrm{pH} 5.21)$ and slightly charged ALG+BSA+TA complex $(\sim(-9) \mathrm{mV})$. The advantageous flux recovery exhibited by the modified membrane after each relaxation cycle suggests weaker interactions between the modified membrane and the ALG+BSA+TA complex, which is the combined result of the reduced contact angle (from 53 to $45^{\circ}$ for the pristine and the modified membrane, respectively) and surface roughness (from 96 to $56 \mathrm{~nm}$ for the pristine and the modified membrane, respectively). During the $2^{\text {nd }}$ run, the modified membrane performed better than the pristine filter, excluding the increased cross-flow velocity strategy (one of three cleaning strategies studied in this work) - which lead to a comparable performance of the two membranes. Hence, the interaction forces between the modified membrane and the ALG+BSA+TA complex are weaker than those between the pristine membrane and the cake layer. This can be explained by the more pronounced hydrophilic properties and the lower roughness of the membranes containing nanoparticles [39, 40]. The similar performance of the two membranes after the increased cross-flow velocity cleaning 
strategy can be explained by the fact that the shear stress generated by a $6 \mathrm{~cm} / \mathrm{s}$ cross-flow velocity was sufficiently high to break the bonds between the ALG+BSA+TA complex and pristine/modified membrane.

Among the three compared cleaning/fouling mitigation strategies, increasing the cross-flow velocity was found to be the most efficient. On the contrary, surface rinsing was found to be the least efficient. Our results suggest that physical cleaning-such as surface rinsing with water and osmotic backwash-are not able to remove the major foulant particles accumulated on the membrane, i.e. the shear stress applied during the cleaning mode is not high enough to destroy the bonds between the membrane and the foulants. Consequently, foulants that are not removed by the cleaning promote the further fouling of the membrane. On the contrary, a higher shear applied in the $2^{\text {nd }}$ run-i.e. the increased cross-flow velocity strategy-reduces the amount of foulants deposited on the membrane surface. Consequently, the degree of membrane fouling is reduced. The superior cleaning efficiency achieved by osmotic backwash compared to surface rinsing can be explained by the fact that the osmotic backwash is removing foulants not only from the membranes' surface but also from the inner structure of the membrane.

The results described in section 3.3 suggest that the binding of silver nanoparticles affected the membranes' charge, hydrophilicity, and roughness. This can be explained by the spherical shape (Figure 11) and zeta potential of the silver nanoparticles, the latter being approximately (-30) $\mathrm{mV}$ at $\mathrm{pH}$ 5.2. ATR-FTIR, XRD, TEM analyses, and antimicrobial tests also proved the presence of silver nanoparticles on the membrane surface. Namely, the suppression of the $1470 \mathrm{~cm}^{-1}$ FTIR peak can be explained by a reaction between carboxyl groups (active layer of the membrane) and cysteamine (bridging agent between the membrane and nanoparticles) (Figure 8) [32], since the $1470 \mathrm{~cm}^{-1}$ peak corresponds to $\mathrm{C}=\mathrm{O}$ stretching and $\mathrm{O}-\mathrm{H}$ bending vibrations of carboxylic acid [33]. Diffraction peaks at $12,18,23$ and $26^{\circ}$ are typical for amorphous polymers [41]. The 
appearance of a new diffraction peak at $38^{\circ}$ (Figure 10) corresponds to the (111) plane of the

421 face-centred cubic structure of metallic silver particles [42]. The results exhibited in Figure 14

422

423 show that the attachment of the nanoparticles to the membrane did not affect the ability of the aquaporin channels to transfer water, i.e. the water flux was unaltered by the binding of the nanoparticles. This means that silver nanoparticles that are covalently bound to the aquaporin membrane do not negatively affect the aquaporins and do not facilitate aquaporin closure. Hence, the binding of silver nanoparticles to aquaporin membranes is an efficient fouling mitigation approach. The experimental results presented in Figure 13 can be explained by the dissipation of the adenosine triphosphate pool and proton motive force (which leads to cell death) [43], the accumulation of intracellular reactive oxygen species [44], and the reaction of silver ions with thiols that deactivate cellular enzymes and DNA [45].

\section{Conclusions}

For the first time, we investigated the controlled complex organic fouling of biomimetic FO membranes and compared the combined organic fouling of pristine membranes with that of aquaporin FO membranes modified by silver nanoparticles. The experiments showed that the complex organic fouling is governed by the interactions between foulants, valency of metal ions present in the feed solution, concentration of the salt, and the spacer's type. Covalent bonding of silver nanoparticles to the membranes allowed to mitigate the water flux decline. Among various cleaning/fouling mitigation techniques, such as surface rinsing with water, osmotic backwash, and increased cross-flow velocity, the latter was found to be the most efficient. By testing the properties of the modified membrane, it was found that the silver coating did not alter water flux through the membrane. The incorporation of the nanoparticles was confirmed by the membranes' zeta potential, contact angle, FTIR, XRD, TEM, AFM analyses and antimicrobial test. The study demonstrated the beneficial use of silver nanoparticles. In long-term experiments the modified 
membranes showed $9-23 \%$ flux decline, while other research groups reported up to $93 \%$

water flux reduction.

Acknowledgments

Funding support from Nazarbayev University is gratefully acknowledged.

\section{Funding sources}

This work was supported by Nazarbayev University (grant number 110119FD4533).

\section{References}

[1] S. Zhao, L. Zou, C.Y. Tang, D. Mulcahy, Recent developments in forward osmosis: opportunities and challenges, J. Membr. Sci. 396 (2012) 1-21.

[2] T. Cath, A. Childress, M. Elimelech, Forward osmosis: principles, applications, and recent developments, J. Membr. Sci. 281 (2006) 70-87.

[3] A. Fuwad, H. Ryu, N. Malmstadt, S.M. Kim, T.-J. Jeon, Biomimetic membranes as potential tools for water purification: preceding and future avenues, Desalination 458 (2019) 97-115.

[4] C. Tang, Y. Zhao, R. Wang, C. Hélix-Nielsen, A. Fane, Desalination by biomimetic aquaporin membranes: review of status and prospects, Desalination 308 (2013) 34-40.

[5] N. Singh, S. Dhiman, S. Basu, M. Balakrishnan, I. Petrinic, C. Helix-Nielsen, Dewatering of sewage for nutrients and water recovery by forward osmosis (FO) using divalent draw solution, J. Water Process Eng. 31 (2019) 100853.

[6] M.S. Camilleri-Rumbau, J.L. Soler-Cabezas, K.V. Christensen, B. Norddahl, J.A. MendozaRoca, M.C. Vincent-Vela, Application of aquaporin-based forward osmosis membranes for processing of digestate liquid fractions, Chem. Eng. J. 371 (2019) 583-592.

[7] C. Schneider, R.S. Rajmohan, A. Zarebska, P. Tsapekos, C. Helix-Nielsen, Treating anaerobic effluents using forward osmosis for combined water purification and biogas production, Sci. Total Environ. 647 (2019) 1021-1030.

[8] J. Xu, T.N. Tran, H. Lin, N. Dai, Removal of disinfection byproducts in forward osmosis for wastewater recycling, J. Membr. Sci. 564 (2018) 352-360.

[9] T. Hey, A. Zarebska, N. Bajraktari, J. Vogel, C. Helix-Nielsen, J. la Cour Jansen, K. Jonsson, Influences of mechanical pretreatment on the non-biological treatment of municipal wastewater by forward osmosis, Environ. Technol. 38 (2017) 2295-2304.

[10] W. Ye, J. Lin, H. Tækker Madsen, E. Gydesen Søgaard, C. Hélix-Nielsen, P. Luis, B. Van der Bruggen, Enhanced performance of a biomimetic membrane for $\mathrm{Na} 2 \mathrm{CO} 3$ crystallization in the scenario of CO2 capture, J. Membr. Sci. 498 (2016) 75-85.

[11] J. Korenak, C. Hélix-Nielsen, H. Bukšek, I. Petrinić, Efficiency and economic feasibility of forward osmosis in textile wastewater treatment, J. Clean. Prod. 210 (2019) 1483-1495.

[12] P. Gena, M. Pellegrini-Calace, A. Biasco, M. Svelto, G. Calamita, Aquaporin membrane channels: biophysics, classification, functions, and possible biotechnological applications, Food Biophys. 6 (2011) 241-249.

[13] T. Hey, N. Bajraktari, J. Vogel, C. Helix Nielsen, J. la Cour Jansen, K. Jonsson, The effects of physicochemical wastewater treatment operations on forward osmosis, Environ. Technol. 38 (2017) 2130-2142. 
[14] Z. Li, R. Valladares Linares, S. Bucs, L. Fortunato, C. Hélix-Nielsen, J.S. Vrouwenvelder, N. Ghaffour, T. Leiknes, G. Amy, Aquaporin based biomimetic membrane in forward osmosis: Chemical cleaning resistance and practical operation, Desalination 420 (2017) 208-215. [15] H. Song, F. Xie, W. Chen, J. Liu, FO/MD hybrid system for real dairy wastewater recycling, Environ. Technol. 39 (2018) 2411-2421. produced fumaric acid using L-alanine as a draw solution, Chem. Eng. Trans. 64 (2018) 259264.

[17] W. Xue, K.K.K. Sint, C. Ratanatamskul, P. Praserthdam, K. Yamamoto, Binding TiO2 nanoparticles to forward osmosis membranes via MEMO-PMMA-Br monomer chains for enhanced filtration and antifouling performance, RSC Advances 8 (2018) 19024-19033.

[18] W. Luo, M. Xie, X. Song, W. Guo, H.H. Ngo, J.L. Zhou, L.D. Nghiem, Biomimetic aquaporin membranes for osmotic membrane bioreactors: Membrane performance and contaminant removal, Bioresour. Technol. 249 (2018) 62-68.

[19] N. Singh, I. Petrinic, C. Helix-Nielsen, S. Basu, M. Balakrishnan, Concentrating molasses distillery wastewater using biomimetic forward osmosis (FO) membranes, Water Res. 130 (2018) 271-280.

[20] J.L. Soler-Cabezas, J.A. Mendoza-Roca, M.C. Vincent-Vela, M.J. Luján-Facundo, L. Pastor-Alcañiz, Simultaneous concentration of nutrients from anaerobically digested sludge centrate and pre-treatment of industrial effluents by forward osmosis, Sep. Purif. Technol. 193 (2018) 289-296.

[21] S. Kalafatakis, S. Braekevelt, A. Lymperatou, A. Zarebska, C. Helix-Nielsen, L. Lange, I.V. Skiadas, H.N. Gavala, Application of forward osmosis technology in crude glycerol fermentation biorefinery-potential and challenges, Bioprocess Biosyst Eng. 41 (2018) 1089-1101.

[22] F.M. Munshi, J. Church, R. McLean, N. Maier, A.H.M.A. Sadmani, S.J. Duranceau, W.H. Lee, Dewatering algae using an aquaporin-based polyethersulfone forward osmosis membrane, Sep. Purif. Technol. 204 (2018) 154-161.

[23] M. Saraswathi, D. Rana, S. Alwarappan, S. Gowrishankar, P. Vijayakumar, N. A., Polydopamine layered poly (ether imide) ultrafiltration membranes tailored with silver nanoparticles designed for better permeability, selectivity and antifouling, J. Ind. Eng. Chem. 76 (2019) 141-149.

[24] S. Rana, U. Nazar, J. Ali, Q.U.A. Ali, N.M. Ahmad, F. Sarwar, H. Waseem, S.U.U. Jamil, Improved antifouling potential of polyether sulfone polymeric membrane containing silver nanoparticles: self-cleaning membranes, Environ. Technol. 39 (2018) 1413-1421.

[25] C. Dong, Z. Wang, J. Wu, Y. Wang, J. Wang, S. Wang, A green strategy to immobilize silver nanoparticles onto reverse osmosis membrane for enhanced anti-biofouling property, Desalination 401 (2017) 32-41.

[26] G.M. Preston, J.S. Jung, W.B. Guggino, P. Agre, The mercury-sensitive residue at cysteine 189 in the CHIP28 water channel, J. Biol. Chem. 268 (1993) 17-20.

[27] L.R. Barone, H. Mu, C.J. Shih, K.B. Kashlan, B.P. Wasserman, Distinct biochemical and topological properties of the 31-and 27-kilodalton plasma membrane intrinsic protein subgroups from red beet, Plant Physiol. 118 (1998) 315-322.

[28] C.M. Niemietz, S.D. Tyerman, New potent inhibitors of aquaporins: silver and gold compounds inhibit aquaporins of plant and human origin, FEBS Lett. 531 (2002) 443-447.

[29] M.C. Martinez-Ballesta, F. Cabanero, E. Olmos, P.M. Periago, C. Maurel, M. Carvajal, Two different effects of calcium on aquaporins in salinity-stressed pepper plants, Planta 228 (2008) $15-25$.

[30] Y. Zhao, C. Qiu, X. Li, A. Vararattanavech, W. Shen, J. Torres, C. Hélix-Nielsen, R. Wang, $\mathrm{X}$. Hu, A. Fane, C. Tang, Synthesis of robust and high-performance aquaporin-based biomimetic membranes by interfacial polymerization-membrane preparation and RO performance characterization, J. Membr. Sci. 423-424 (2012) 422-428. 
[31] J.W. Slot, H.J. Geuze, A new method of preparing gold probes for multiple-labeling 540 cytochemistry, Eur. J. Cell Biol. 381 (1985) 87-93.

541 [32] A. Soroush, W. Ma, Y. Silvino, M.S. Rahaman, Surface modification of thin film composite 542 forward osmosis membrane by silver-decorated graphene-oxide nanosheets, Environ. Sci. Nano 5432 (2015) 395-405.

544 [33] S.F. Seyedpour, A. Rahimpour, G. Najafpour, Facile in-situ assembly of silver-based MOFs to surface functionalization of TFC membrane: a novel approach toward long-lasting biofouling mitigation, J. Membr. Sci. 573 (2019) 257-269.

[34] A. Antony, R. Fudianto, S. Cox, G. Leslie, Assessing the oxidative degradation of polyamide reverse osmosis membrane - accelerated ageing with hypochlorite exposure, J. Membr. Sci. 347 (2010) 159-164.

[35] E. Kaspchak, A.C. Goedert, L. Igarashi-Mafra, M.R. Mafra, Effect of divalent cations on bovine serum albumin (BSA) and tannic acid interaction and its influence on turbidity and in vitro protein digestibility, Int. J. Biol. Macromol. 136 (2019) 486-492.

[36] E. Arkhangelsky, F. Wicaksana, C. Tang, A.A. Al-Rabiah, S.M. Al-Zahrani, R. Wang, Combined organic-inorganic fouling of forward osmosis hollow fiber membranes, Water Res. 46 (2012) 6329-6338.

[37] E. Arkhangelsky, F. Wicaksana, A.A. Al-Rabiah, S.M. Al-Zahrani, R. Wang, Understanding the interaction between biomacromolecules and their influence on forward osmosis process, Desalination 385 (2016) 12-23.

[38] G.T. Grant, E.R. Morris, D.A. Rees, P.J. Smith, D.H. Thom, Biological interactions between polysaccharides and divalent cations: the egg-box model, FEBS Letters 32 (1973) 195198.

[39] J. Ahmad, X. Wen, F. Li, B. Wang, Novel triangular silver nanoparticle modified membranes for enhanced antifouling performance, RSC Advances 9 (2019) 6733-6744.

[40] Z. Chen, J. Luo, X. Hang, Y. Wan, Physicochemical characterization of tight nanofiltration membranes for dairy wastewater treatment, J. Membr. Sci. 547 (2018) 51-63.

[41] C. Van Goethem, R. Verbeke, M. Pfanmöller, T. Koschine, M. Dickmann, T. TimpelLindner, W. Egger, S. Bals, I.F.J. Vankelecom, The role of MOFs in thin-film nanocomposite (TFN) membranes, J. Membr. Sci. 563 (2018) 938-948.

[42] S.-F. Pan, X.-X. Ke, T.-Y. Wang, Q. Liu, L.-B. Zhong, Y.-M. Zheng, Synthesis of silver nanoparticles embedded electrospun PAN nanofiber thin-film composite forward osmosis membrane to enhance performance and antimicrobial activity, Ind. Eng. Chem. Res. 58 (2018) 984-993.

[43] C.-N. Lok, C.-m.R. Ho, R.S. Chen, Q. He, W.-Y. Yu, H. Sun, P.K.-h. Tam, J.-f. Chiu, C. Che, Proteomic analysis of the mode of antibacterial action of silver nanoparticles, J. Proteome Res. 54 (2006) 916-924.

[44] O. Choi, Z. Hu, Size dependent and reactive oxygen species related nanosilver toxicity to nitrifying bacteria, Environ. Sci. Technol. 42 (2008) 4583-4588.

[45] O. Choi, K.K. Deng, N.J. Kim, L. Ross, Jr., R.Y. Surampalli, Z. Hu, The inhibitory effects of silver nanoparticles, silver ions, and silver chloride colloids on microbial growth, Water Res. 42 (2008) 3066-3074. 